\title{
Genetic Approaches to Enhance Multiple Stress Tolerance in Maize
}

\author{
Nenad Malenica $^{1}$, Jasenka Antunović Dunić ${ }^{2}$ (D), Lovro Vukadinović ${ }^{3}$, Vera Cesar ${ }^{2,4}$ and Domagoj Šimić $^{3,5, *(\mathbb{D})}$ \\ 1 Division of Molecular Biology, Faculty of Science, University of Zagreb, Horvatovac 102a, \\ 10000 Zagreb, Croatia; malenica@biol.pmf.hr \\ 2 Department of Biology, Josip Juraj Strossmayer University, Cara Hadrijana 8/A, 31000 Osijek, Croatia; \\ jantunovic@biologija.unios.hr (J.A.D.); vera.cesar@biologija.unios.hr (V.C.) \\ 3 Agricultural Institute Osijek, Južno Predgrađe 17, 31000 Osijek, Croatia; lovro.vukadinovic@poljinos.hr \\ 4 Faculty of Dental Medicine and Health, Josip Juraj Strossmayer University of Osijek, Crkvena 21, \\ 31000 Osijek, Croatia \\ 5 Centre of Excellence for Biodiversity and Molecular Plant Breeding (CroP-BioDiv), Svetošimunska 25, \\ 10000 Zagreb, Croatia \\ * Correspondence: domagoj.simic@poljinos.hr; Tel.: +385-31-515-521
}

Citation: Malenica, N.; Dunić, J.A.; Vukadinović, L.; Cesar, V.; Šimić, D. Genetic Approaches to Enhance Multiple Stress Tolerance in Maize. Genes 2021, 12, 1760. https:/ / doi.org/10.3390/genes12111760

Academic Editor: Qingyi Yu

Received: 11 October 2021

Accepted: 3 November 2021

Published: 4 November 2021

Publisher's Note: MDPI stays neutral with regard to jurisdictional claims in published maps and institutional affiliations.

Copyright: (c) 2021 by the authors. Licensee MDPI, Basel, Switzerland. This article is an open access article distributed under the terms and conditions of the Creative Commons Attribution (CC BY) license (https:/ / creativecommons.org/licenses/by/ $4.0 /)$.

\begin{abstract}
The multiple-stress effects on plant physiology and gene expression are being intensively studied lately, primarily in model plants such as Arabidopsis, where the effects of six stressors have simultaneously been documented. In maize, double and triple stress responses are obtaining more attention, such as simultaneous drought and heat or heavy metal exposure, or drought in combination with insect and fungal infestation. To keep up with these challenges, maize natural variation and genetic engineering are exploited. On one hand, quantitative trait loci (QTL) associated with multiplestress tolerance are being identified by molecular breeding and genome-wide association studies (GWAS), which then could be utilized for future breeding programs of more resilient maize varieties. On the other hand, transgenic approaches in maize have already resulted in the creation of many commercial double or triple stress resistant varieties, predominantly weed-tolerant/insect-resistant and, additionally, also drought-resistant varieties. It is expected that first generation gene-editing techniques, as well as recently developed base and prime editing applications, in combination with the routine haploid induction in maize, will pave the way to pyramiding more stress tolerant alleles in elite lines/varieties on time.
\end{abstract}

Keywords: maize; multiple-stress tolerance; quantitative genetics; genetic engineering

\section{Introduction}

Maize (Zea Mays L.) is, together with wheat and rice, one of the three cereals that feed the world. As a major crop worldwide, maize is essential for industry and it is cultivated mostly in rainfed cropping systems where changes in climate, erosion and a dwindling water supply threaten to diminish future yields [1]. The most important trait in maize is grain yield, a composite trait that is influenced by many stress-related traits. Research on yield potential and stress tolerance in maize, combined with extensive phenotypic selection, has helped achieve significant genetic gains in rain-fed yield of maize hybrids [2]. Tollenaar and Lee [3] stated that the genetic yield improvement of North American maize varieties during the 20th century is closely associated with enhanced stress tolerance.

The main stresses that affect maize plant in the field are being extensively studied. They include drought [4,5], heat [6], chilling [7-9], flood [10], fungi and viruses [11,12], parasitic plants [13], insects [14], pesticides [15], herbicides [16,17], heavy metals [18,19], poor nutrients $[20,21]$, soil salinity [22] and soil acidity [23,24]. Ongoing climate change is expected to aggravate this burden. Globally, it was projected that climate change could affect yield reduction in maize by an average of $7.4 \%$ for every $1{ }^{\circ} \mathrm{C}$ increase in mean temperature [25]. Yet, percentage yield change as a function of temperature is not the 
same in tropical and temperate regions [26] and it could even be positive according to the Intergovernmental Panel on Climate Change Fourth Assessment Report (IPCC AR4) [27]. However, if additional stress factors, such as nitrogen deficiency, are to be included, according to the results of seven global gridded crop models, a negative percentage yield change could be drastic, especially in tropical regions [28].

Drought, as the second most important cause of yield loss for maize after poor soil fertility, affects $20-25 \%$ of the global maize area each year [29]. Maize is quite drought susceptible compared to other cereals, with the exception of rice. This has considerable consequences, as most of the maize producing areas are under rainfed conditions [30]. Moreover, if a long-term drought occurs in either a jointing or tasseling period for more than 30 days, no plant recovery is possible, even after irrigation [31]. In order to escape drought, the coordination of phenology with water availability can be performed choosing maize genotypes of early maturity [32]. However, choosing early maize hybrids may not be an optimum option, since these hybrids can be more sensitive to heat stress than late hybrids [33]. Generally, the strategies of drought escaping or avoiding are commonly used in maize where stress can be circumvented by earlier planting dates or planting earlier hybrids to avoid the assumed adverse weather conditions mostly during flowering. However, the global trends in temperature and precipitation suggest that extreme weather events may occur at any time throughout the growing season, including a cold spring and late spring frost, thus making an early planting date or early genotypes not worthwhile [33]. Thus, it seems that seeking for drought resistance is actually seeking for drought tolerance, defined as a potential for plants to maintain their growth and development under drought stress [32]. Aslam et al. [32] gave an overview of numerous adaptation mechanisms at the physiological and molecular levels conferring drought tolerance. At the physiological level, they include osmotic adjustment, antioxidative defense mechanism and plant growth regulators. Molecular mechanisms comprise stress proteins and water channel proteins, transcription factors and signal transduction pathways.

Up until recently, research on heat stress in maize is not as exhaustive as research on drought. However, Lobell et al. [34] demonstrated that extreme heat as a stressor had a more critical role for maize production than drought in the US, corroborating previous statistical studies of rainfed maize yields showing a strong negative yield response to the accumulation of extreme temperatures $\left(>30^{\circ} \mathrm{C}\right)$ and a relative weak response to seasonal rainfall. A leaf temperature above $30^{\circ} \mathrm{C}$ affects net photosynthesis because of rubisco inactivation [35], but there is notable acclimation when the temperature increase was gradual $\left(2.5^{\circ} \mathrm{C} \mathrm{h}^{-1}\right.$ from 28 to $\left.45^{\circ} \mathrm{C}\right)$ rather than abrupt $\left(1^{\circ} \mathrm{C} \cdot \mathrm{min}^{-1}\right.$ for the same temperature range) [36]. Hasanuzzaman et al. [37] listed two major effects of heat stress in maize during flowering on plant and ear growth rates, and in the reproductive stage on ear expansion. Similar to drought, there are several adaptation mechanisms at the physiological and molecular levels conferring heat tolerance, such as the following: osmoprotectants, antioxidative defense, expression of stress proteins, signaling cascades and transcriptional control [37].

Another abiotic, e.g., an anthropogenic stressor important for crop production, is heavy metal excess in the soil, representing a threat on the environment due to its toxicity to plants, animals and humans. The most important heavy metal in maize is cadmium that induces growth inhibition, changes in the water and ion metabolism, the inhibition of photosynthesis, changes in enzyme activities and the formation of free radicals [18,38]. Defense mechanisms comprise immobilization, synthesis of phytochelatins, as well as similar physiological mechanisms present under drought and heat conditions, including an accumulation of stress proteins, proline and salicylic acid [18]. Generally, responses to heavy metal toxicity involve an accumulation of reactive oxygen species (ROS), abscisic acid (ABA) and stomatal closure, but an antioxidant defense can be distinct in different organs when maize plants are subjected to sub-lethal concentrations of cadmium, copper, nickel and zinc [39]. Further, physiological implications and the toxicity of chromium, copper and mercury in the maize plant were also assessed [40]. A special case of an anthropogenic stressor in maize is high plant density. It is associated with nitrogen use 
stress and drought [41] due to plant competition generating multiple-stress environments and eventually affecting plant physiology, phenology and morphology [42].

Beside European Corn Borer (Ostrinia nubilalis L.), the two most prominent biotic stressors in maize are Diabrotica and Fusarium, which are interrelated with abiotic stressors $[43,44]$. The western corn rootworm (Diabrotica virgifera virgifera LeConte) is one of the major pests of maize in Europe and in the USA. Once detected, it is very difficult to eradicate as well as to manage. Efforts for identifying sources of resistance to corn rootworm within maize cultivars are crucial [45]. Apart from studying natural genetic variation via quantitative genetics and classical breeding, several biotech companies developed the first transgenic (genetically modified-GM) maize cultivars by transferring insecticidal protein gene(s) from bacterium Bacillus thuringiensis, Berliner (Bt) into maize ('Bt maize') [46], as an alternative to chemical control and crop rotation for insect control. However, the development of maize hybrids with native resistance to insects would be a sustainable management tool [45].

Climate change resulting in higher temperatures and less rainfall, largely favors the development of fungus Fusarium sp. Fusarium verticillioides is less pathogenic and a higher disease intensity only occurs if the plant has been previously weakened by other biotic or abiotic stress [47]. The infection of maize with F. verticillioides can lead to a contamination of the grain with mycotoxin fumonisin synthesized by fungi during development. CamposBermudez et al. [48] presented a combination of biochemical and molecular approaches to clarify metabolic changes following maize infection with F. verticillioides.

Due to the complex interaction among different stresses, only a tiny fraction of studies on plant responses to stresses deals with the combinations of two or more stresses. A closer inspection of the database search revealed that only about $1 \%$ of the original articles had stress combination as a subject [49]. However, this could be changed due to extensive research on climate change and its multifactorial nature affecting unpredictable combinations of different stresses and posing an even greater threat to major crops [50]. Mittler [51] proposed a stress matrix approach to visualize the individual positive and/or negative interactions among different stresses and their overall effect on plant growth and yield. At this two-dimensional level, the majority of the interactions among the stresses seem to be negative [52]. When more than two stress factors co-occur, a severe decline in the subsequent plant growth and survival takes place. Zandalinas et al. [53] defined a multifactorial stress combination as a combination of three or more simultaneous stress factors grouping in the following four major threats: anthropogenic, biotic, climate and soil threats. The four threats that include agronomically important stress factors in maize are presented in Figure 1. They affect the supply of nutrients, water uptake, growth, respiration, photosynthesis, transpiration, reproduction of maize plant and, eventually, yield. Once additional stresses are presented, even at low levels, they could negatively interact with each other and bring about substantial decreases in agricultural productivity [53].

The most investigated stress combination in maize is drought and heat, predominantly in African environments [54-59]. In a simulation study, it was demonstrated that incorporating combined drought and heat tolerance into maize tropical varieties may increase grain yield under both the baseline and future climate scenarios [60]. In Africa, there is also a research interest in multiple-stress tolerance to drought and the parasitic plant of Striga hermonthica [61], as well as to a Striga, low soil nitrogen and drought combination [62]. In tropical rainfed environments in general, climate-induced stressors are drought, heat, waterlogging, salinity, cold, diseases and insects, which frequently come in different combinations [63]. Elsewhere, there are studies on the interactions between insects and other stress factors such as salinity [64], flooding [65] and on the interaction between pesticides and salinity [66]. The combined stress of flooding and infestation with the insect pest Spodoptera frugiperda (fall armyworm) leads to an elevated production of salicylic acid, which does not occur in the individual stresses [65]. Studies on a combination of the three simultaneous stress factors in maize are scarce. The combination of Striga, low soil nitrogen and drought was investigated in Nigeria [62]. Based on the multiple-trait 
selection index, the top low-N, Striga and drought tolerant/resistant maize genotypes were recognized as vital sources of beneficial alleles for the improvement of tropical yellow maize germplasm. The combination of drought, insect infestation and Fusarium in the context of fumonisin contamination was examined in California [67]. The significant main effects of hybrid, planting date, insecticide treatment and drought stress on Fusarium ear rot symptoms and fumonisin B1 contamination were detected, and these factors also had significant interacting effects. Recently, the combination of drought, heat and the effect on some arthropod pests was reviewed [68] focusing on mechanisms of physiological, biochemical and molecular responses previously given by Aslam et al. [32]. To conclude, Chávez-Arias et al. [68] summarized the following impacts of the combination of heat and drought on the physiological responses of maize plants: decrease in yield, increase in days from anthesis to silking, reduction in growth parameters (height, stem diameter, leaf area, fresh and dry weight), changing water status and nutrient content, decrease in chlorophyll content and gas exchange parameters such as photosynthesis, stomatal conductance and transpiration, reduction in fresh and dry weights, as well as increase in leaf temperature.

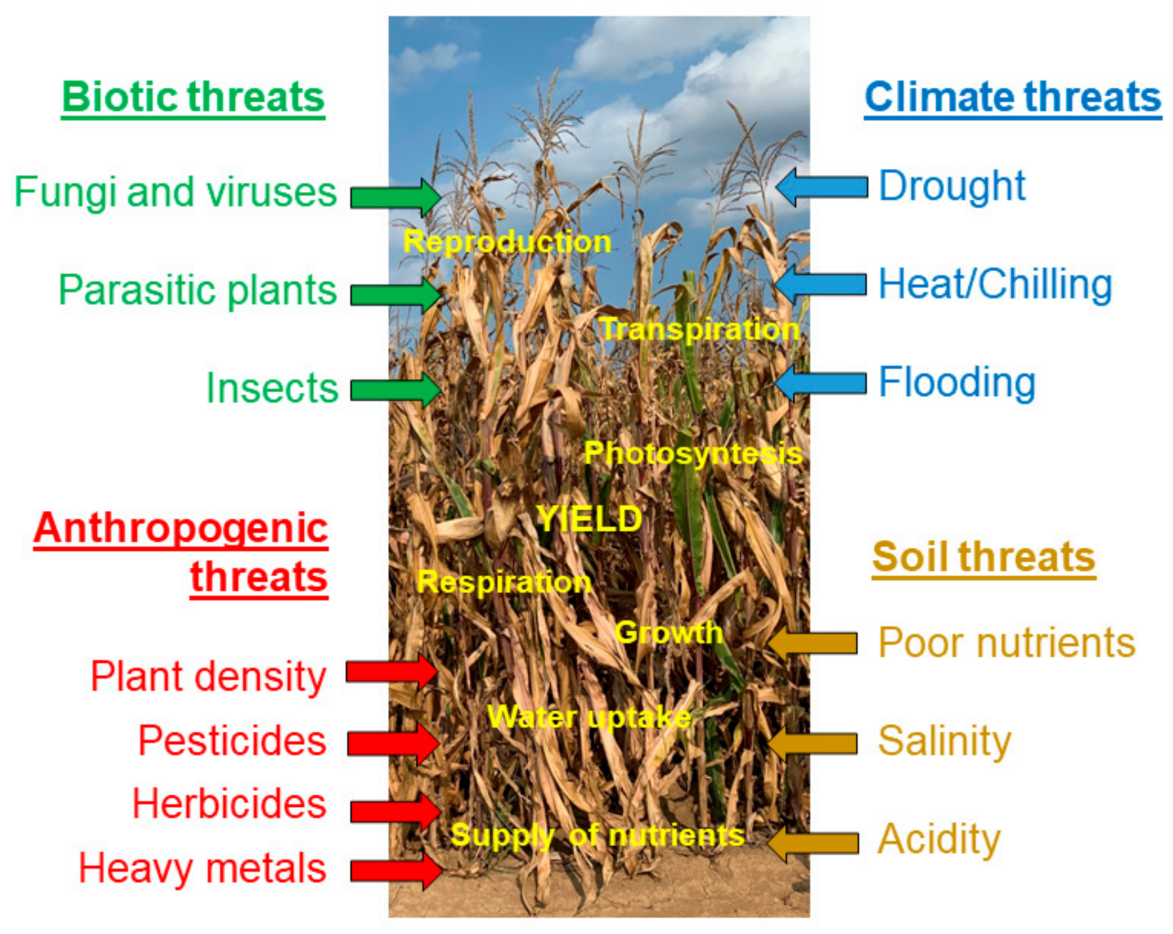

Figure 1. Most important stress factors in maize. Adapted from Zandalinas et al. [53].

\section{Physiological Traits for Screening Genotypes for Multiple-Stress Tolerance}

While many stress responses appear to be stress-type-specific, it is clear that some stress responses are more general and potentially confer tolerance to multiple types of stressors [69]. As mentioned above, an accumulation of some osmoprotectants, such as proline and other amino acids, or changing the concentrations of some antioxidants represent a plant response on several individual stressors (e.g., drought, heat, heavy metal toxicity). By investigating leaf metabolites and yield under drought, heat and combined drought and heat conditions in the field, Obata et al. [70] found that drought stress evoked the accumulation of various amino acids (isoleucine, valine, threonine, 4-aminobutanoate, glycine, serine and myoinositol), while the combination of drought and heat evoked relatively few specific responses. Most of the metabolic changes were predictable from the sum of the responses to individual stresses. However, drought stress can have a predominant effect overheat stress, although total soluble sugars, proline and total free amino acids were increased under all the stress treatments [71]. 
Abiotic stress factors produce highly reactive forms of oxygen capable of rapidly reacting with and oxidizing numerous cellular constituents (e.g., proteins, lipids, DNA, RNA) depending on stress severity and duration. These toxic intermediates, reactive oxygen species (ROS), can disturb the metabolic processes of cells and, consequently, lead to cell death. Plants have evolved efficient antioxidant mechanisms, enzymatic and non-enzymatic, to cope with ROS overproduction. A large number of ROS detoxifying proteins (superoxide dismutase (SOD), catalase (CAT), ascorbate peroxidase (APX), guaiacol peroxidase (POD), glutathione peroxidase (GPX), glutathione reductase (GR), etc.) and non-enzymatic antioxidants such as ascorbic acid or glutathione are present in cells. The details of ROS production and ROS defense pathway were documented and discussed in numerous review papers [72-76]. The substantial imbalance between ROS production and scavenging has been shown in maize and other crops dealing with cadmium toxicity $[77,78]$ or drought [79-82]. However, the antioxidative response proved to be strongly genotype-dependent. Oxidative damage and the antioxidative response were different in the leaves of two diverse maize inbred lines $[83,84]$ subjected to excess cadmium in soil, water limitation as well as to a combination of both stress factors [85]. A gradual significant increase in POD activity was observed in one inbred line across the following three treatments: Cd excess, water limitation and a combination of both, but not in other one. The opposite case was with proline activity where a dramatic increase occurred only in the second inbred line under water limitation and stress combination conditions.

The protective role of proline in osmotic adjustment is well documented [86-88]. Increased proline indicated that cadmium provoked certain genotypes to synthesize more proline to resist osmotic stress, as also assumed by Zhao et al. [89].

These results suggest that different strategies of antioxidative mechanisms could be present in maize inbred lines subjected to water limitation, excess cadmium and a combination of both stress factors, indicating existing multiple-stress tolerance in some genotypes. The same is true for the combination of drought and heat [54] to identify combined drought and heat tolerant donors. However, there was a genotype by trial interaction, and tolerance to combined drought and heat stress was genetically distinct from tolerance to individual stresses, whereby tolerance to either stress alone did not confer tolerance to its combination. Nevertheless, tolerance to drought, heat, cadmium toxicity and other stressors under multiple stress conditions requires further extensive genetic and physiological research in order to identify and use tolerant genotypes for breeding for an adaptation under climate change.

All stress factors, directly or indirectly, inhibit the most important physiological process of photosynthesis as a global sensor of environmental stress in plants [90]. In the last few decades, chlorophyll $a$ fluorescence measurement, as a rapid and non-destructive method, was recognized as a useful tool for screening plant sensitivity to various stress factors [77-79,91,92]. The illumination of dark-adapted leaves using actinic light for 1 $\mathrm{s}$ enables a polyphasic chlorophyll $a$ fluorescence induction curve to be obtained (O-JI-P transient). An interpretation of the JIP-test, a mathematical model developed by Strasser [93], provides exhaustive information dealing with the structure and function of the photosynthetic apparatus [91,93].

Numerous studies have shown different responses provoked by adverse environmental features, depending on the crop species, genotype, stress type and duration and developmental stage. The fluorescence parameters are being used extensively in stress physiology in a range of plant species under controlled conditions and it is also easily adaptable to field conditions [94]. This is particularly important for maize, because stress studies conducted under controlled conditions inadequately reflect natural environmental conditions. While the impact of the following individual stress factors on maize's photosynthetic efficiency has been well documented: drought [94-96], heat [35,97], chilling [98], fungi [99], herbicides [100], herbicides and cadmium [101], cadmium alone [84,102], low nitrogen [103], soil salinity $[64,104,105]$ and plant density [106], there is a lack of information dealing with the multiple stress tolerance. Qu et al. [107] have monitored the 
effect of a combination of potassium deficiency and salt stress in maize seedlings grown in controlled conditions. The obtained results revealed that a combination of investigated stress factors impaired the light reaction pathways of PSI and PSII and resulted in severe photochemical damage in leaves if compared with the ones affected by individual stress factors. Correia et al. [108] investigated the contrasting levels of tolerance to drought and heat of two maize genotypes, B73 (heat and sensitive) and P0023 (drought-tolerant hybrid). Limited transpiration under heat and drought allowed water savings to act as a drought stress avoidance mechanism. A higher phosphorylated phosphoenolpyruvate carboxylase (PEPC) and electron transport rate (ETR) in P0023 maintained the photosynthetic efficiency. A limited transpiration rate and a synchronized carbon assimilation regulation were identified as the key traits for drought and heat tolerance in maize [108]. A combination of excess cadmium and drought stress were tested in lines Os6-2 and B84, and in their hybrid [109]. A decreased total performance index, $\mathrm{PI}_{\text {tot }}$, a parameter that comprises the functional activity of photosystem II, photosystem I and intersystem electron transport chain, was reported in Os6-2 and in hybrid. The destabilization of the oxygen evolving center of PSII (OEC) and a lower PS stability were also observed. Photoinhibition due to the stress combination also occurred in line B84, despite an unchanged $\mathrm{PI}_{\text {tot }}$, the most sensitive parameter of the JIP-test. The results suggested that all the investigated maize genotypes have developed different strategies to cope with a combination of excess cadmium and drought. The possibility of obtaining exhaustive information about leaf photochemistry during real-time in situ monitoring in field conditions, as well as the other technical advantages of chlorophyll $a$ fluorescence approaches, have made it a popular technique for crop phenotyping.

\section{Strategies for Enhancing Multiple-Stress Tolerance in Maize}

\subsection{Natural Genetic Variation}

The main genetic approach to the enhancement of multiple-stress tolerance is utilizing the natural genetic variation of plant quantitative traits associated with stress tolerance where quantitative genetics play a pivotal role via classical and molecular breeding. Although quantitative genetics has entered the second century, it still serves as the genetic basis of contemporary plant breeding $[110,111]$ and maize breeding in particular [112]. Virtually all the studies on stress tolerance already mentioned in this review are directly or indirectly related to classical maize breeding. In this chapter, the focus is on molecular breeding, i.e., genetic mapping identifying quantitative trait loci (QTL) [113] and genomewide association studies (GWAS) [114] on multiple-stress tolerance traits in maize. Briefly, maize genetics and a genomic database [115] search using the keyword "stress" within a "Loci+QTL" data subset [116] retrieved a total of 90 genes and loci directly related to stress factors. Among others, there are 39 genes belonging to aasr (Abscisic acid-ABA stress-ripening) and hsftf (heat stress transcription factor) families, as well as "universal/general stress protein" genes pco103004, pco143261, pco144726 and pco152469. There are a total of 27 retrieved quantitative trait loci: 20 associated with drought ("qgyldws" loci), 6 "stressed-leaf ABA content" QTL ("qslaba" loci) and one "unstressed-leaf ABA content" QTL ("qulaba" locus). Otherwise, there is a plethora of QTL experiments dealing with stress in maize: according to Web of Science Core Collection Database [117], more than 400 articles are currently to be retrieved in this regard. On the other hand, the number of studies on molecular breeding for multiple-stress tolerance in maize is limited, although advanced models for multi-trait QTL analysis were known for more than a decade, (e.g., [118]).

In a field experiment including stress treatment blocks (drought, low nitrogen and combined), Makumburage and Stapleton (2011) [119] examined phenotype uniformity and mapped QTL in IBM94 intermated recombinant inbred lines [120]. They concluded that phenotype uniformity, which is genetically controlled, has a different genetic architecture in multiple-stress environments compared to single-stress blocks. In an associated article, the genetic architecture of drought and ultraviolet radiation stresses along with their combination was examined in two maize mapping populations, revealing the complex 
attenuating interactions among physiological signaling steps in two stress responses [121]. Recently, combined drought and heat stress tolerance was examined in the DTMA (Drought Tolerant Maize for Africa) association-mapping panel [122], including 300 tropical and subtropical maize inbred lines genotyped with genotyping-by-sequencing (GBS) [123]. This GWAS mapping revealed few overlapped significant markers and candidate genes for the same traits across different stress environments, showing the genetic divergence between the individual stress tolerance and the combined drought and heat tolerance. Another GWAS mapping revealed that only one GWAS-base candidate gene was associated with each of the five of the six combined insect resistance quantitative trait nucleotides (QTNs), thus supporting the pleiotropy hypothesis [124]. Nevertheless, the delivered multiple insect resistance physical map should contribute to the possible enhancement of combined insect resistance in maize. Hou et al. [125] used an IBM Syn10 DH population [126] to detect the quantitative trait loci (QTL) for a combined lead and cadmium tolerance by linkage mapping in maize seedlings contributing to functional gene identification and molecular breeding for improving heavy metal tolerance.

Quantitative genetic studies have identified genetic correlations among stress-resistance traits, such that the selection of tolerance to one type of stress has been associated with tolerance to another type of stress as a correlated selection response [127]. However, due to a significant genotype by environment interaction, these associations are generally not clear. Furthermore, genetic correlations for grain yield between the means under drought and combined drought and heat conditions, as well as under heat and combined drought and heat conditions were negligible ( 0.08 and -0.07 , respectively) [54]. At the molecular level, certain heat-shock proteins are commonly elicited in response to various stress conditions [128]. The Putative pleiotropic candidate gene for the quantitative trait locus (QTL) detected on maize chromosome 7, associated with several chlorophyll fluorescence parameters, seemed to be gst23 [94]. It belongs to the large glutathione transferase gene family that encodes glutathione transferase, which have an important role in plant responses to abiotic and biotic stresses [73]. Mullineaux and Karpinski [129] stated that in Arabidopsis, some compounds (oxylipins) during abiotic and biotic stresses may induce the expression of a gst gene. The pleiotropy of a gst gene was identified for three maize diseases [130], suggesting the importance of glutathione transferase in response of maize to biotic stress. However, Wallace et al. [112] stated that the majority of QTLs are not pleiotropic and the presumed correlation between quantitative traits seems to be due to the population structure. The putative association of the gst 23 gene with five chlorophyll fluorescence parameters might suggest that glutathione transferase is linked with the regulation of photon absorbance and exciton dissipation, as well as in the trapping/dissipation ratio and, therefore, provides biological and biochemical plausibility that this member of the maize gst family is associated with photosynthetic efficiency in general, and eventually with multiple-stress tolerance. The same might be true for maize Mitogen-Activated Protein Kinase Kinase Kinase (MAPKKK) [131]. In transgenic Arabidopsis, NDP kinase interacts with two MAPKs enhancing the multiple-stress tolerance [132].

Generally, stress tolerance is a polygenic trait controlled by many genes, and most of these genes have minor effects [133]. Therefore, classical linkage or QTL analysis in maize achieved limited success in improving polygenic complex traits due to the low power of detecting minor effects, coarse mapping and capturing limited genetic diversity in mostly biparental populations. However, some stress-related traits such as cadmium accumulation seem to be controlled by only a few major genes [83] reconsidering the classical marker assisted selection as a tool for contemporary plant breeding [134]. On the other hand, GWAS was more successful in the identification of thousands of genomic regions associated with many stressors, revealing a natural variation for stress tolerance and physiological traits in the diverse genetic material of maize [135]. GWAS has also some disadvantages though, including providing false positive/false negative associations and a weak identification of rare allelic variants [135]. Nevertheless, the ultimate dissection 
of a phenotype can only be completed with a direct connection with a DNA sequence variation [136], which the QTL/GWAS framework has not been able to provide thus far.

\subsection{Genetic Engineering}

In addition to traditional breeding and molecular breeding approaches, in the last two decades, we have witnessed a global expansion of genetically engineered (genetically modified-GM), i.e., transgenic, maize varieties. Since the approval of the first transgenic maize varieties such as MON 809 and MON810 in the USA in 1996, the numbers of authorized and cultivated GM maize varieties are steadily rising. Currently, three comprehensive databases of cultivated GM crops hold the following entries for GM maize: the International Service for the Acquisition of Agri-biotech Applications (ISAAA) lists 240 [137], the Biosafety Clearing House (BCH) 298 [138] and the Food and Agriculture Organization GM Foods Platform (FAO), 179 entries [139]. A recent extensive meta-analysis showed that GM maize varieties, during their two decades of cultivation (1996-2016), resulted in multiple benefits for the farmers, consumers and the environment by increasing the grain yield, reducing the mycotoxin content and sparing non-target organisms, respectively [140]. The same study reports that GM maize represents one-third of all the planted maize globally. In the context of multiple-stress tolerance, the first GM maize varieties, e.g., MON809, was already designed to fight the following two biotic stressors simultaneously: weeds, via its herbicide (glyphosate) tolerance trait [120], and lepidopteran insect resistance, via the encoded $B t$ toxin family protein, Cry1 Ab endotoxin. MON809 was produced by biolistic cotransformation and the cointegration of a plasmid harboring the Cry $1 \mathrm{Ab}$ gene and a second plasmid harboring C4 EPSPS and gox genes for glyphosate tolerance. However, in this particular case, the glyphosate tolerance trait was not efficient in field conditions. Therefore, the desired trait combination of insect resistance and herbicide tolerance was added by conventionally breeding two single-trait varieties, generating one of the first two-stacked events MON810 $\times$ MON88017 [120]. In principle, the term stacking means to combine several traits in a single maize variety. It can be achieved in the following ways: (a) by the cotransformation/cointegration of two or more T-DNA plasmids/linear DNA fragments [141] such as in the case MON809; (b) by transgene design, where all the traits/genes are cloned into one T-DNA or biolistic DNA fragment the like in the case of "Golden rice" harboring three genes on a single T-DNA [142]; (c) by conventional crossbreeding of different thoroughly characterized single-trait GM varieties, the so-called events. Stacking by crossbreeding is favored over the cotransformation or retransformation approaches [141] for regulatory reasons: national authorities tend to fast track breeding stacks generated by single-trait GM varieties that have been previously characterized and approved. On the other hand, the retransformation of an approved GM maize variety with another T-DNA construct would have to be evaluated de novo.

Additionally, a point to consider is that stacked events have, in principle, a hemizygous genotype, i.e., they have just one and not two T-DNA copy per locus. This is because commercial stacked events are F1 hybrids of elite inbred lines. As new traits are added, the generation of corresponding parental lines becomes more time-consuming. Fortunately, maize breeders have a genetic tool to make this problem easier to tackle: haploid inducer lines. The Stock6 haploid inducer was described decades ago [143] and was used commercially without the understanding of the molecular mechanism. Recently, it was shown that a mutation in MATRILINEAL (MTL), a pollen-specific phospholipase, is responsible for the HI phenotype of Stock6 [144,145]. In addition, another haploid inducing approach was established in maize, which is based on the previously CENH3-mediated haploid induction $[146,147]$. In maize, the haploid inducing capacity is provided by the heterozygous (+/cenh3) genotype. These HI lines will have an important role in increasing the breeding speed of maize multiple-stress tolerant stacks in the future.

Today, maize breeding stacked events are the most represented multi-stress tolerant commercial varieties. For example, $79 \%$ of the maize acres in the USA were planted with stacked varieties in 2020 [148]. Thus far, the following three stress-related traits have been 
successfully stacked in maize: insect resistance, herbicide tolerance and drought tolerance. Currently, the most complex maize stacks in cultivation are constituted of up to six different GM varieties (Table 1).

The six-stacked varieties were produced by the classical cross-pollination of six independent single-trait varieties, which were previously approved for cultivation [149]. However, the number of expression cassettes per variety is higher: some of the six-stacked varieties have up to three different herbicide resistance genes, up to six different natural or chimeric Cry proteins as well as one dsRNA expression cassette conferring insect resistance via the RNA interference pathway. Concerning possible interactions of individual transgenes in multi-stacked events, it is possible in theory, but highly unlikely, because the stacks were generated by the crosspollination of single events. Each single event was inserted in the maize genome randomly and independently. Therefore, the chance of inter-event recombination is not significant.

Moreover, stacking multiple insect resistance genes not only helps to improve yields due to warding off more insect types, but also due to the reduction in the mandatory nonGM refuge area proposed by the regulatory agencies, e.g., the Environmental Protection Agency (EPA). In the USA, a reduction in the non-Bt corn area from 20 to $5 \%[150,151]$ is allowed for stacked maize varieties.

The evolution of Bt resistance was slowed down and is still under control in countries that promote the mandatory planting of non-GM maize refuge areas. On the contrary, herbicide-resistant weeds appeared soon after the beginning of a mass application of glyphosate. There are the following strategies for controlling weed resistance: 1 . increasing the herbicide concentration to the maximum a GM plant can tolerate; 2 . increasing the copy number of herbicide-resistance genes by stacking (see Table 1); and 3. combining different herbicide resistance genes. Although immediately effective, none of these strategies is a sound long-term solution. In retrospect, it would have been reasonable that mandatory yearly crop rotation was promoted, or that a yearly exchange of different herbicides in combination with the corresponding resistance genes were applied.

The number of traits and genes that will need to be transformed or crossed into elite maize lines will grow in the future. Besides the current crossbreeding strategy, other advanced techniques for introducing large number of genes are in the pipeline, including the following: polycistronic expression in chloroplast [152], Binary Bacterial Artificial Chromosomes [153] or mini chromosomes [154,155]. However, all of these approaches still await routine use.

Apart from the classical transgenic approach, genome editing is the next breeding advancement that will enable new multiple-stress tolerant variety development $[156,157]$. The first use of the sequence-directed endonucleases such as TALEN and CRISPR/Cas9 in maize was demonstrated in protoplasts [158]. In addition, gene editing in planta was demonstrated on immature maize embryos, which were targeted by biolistic transformation. Maize monoallelic and biallelic mutations were successfully identified at ASL2 (acetolactate synthase), LIG1 (liguleless1) and two fertility loci, Ms26 and Ms45 [159]. Importantly, some edited plants were not transgenic, indicating only a transient expression of the Cas9-gRNA plasmid. This is important in respect to the negative public perception of transgenic plants. Svitashev et al. (2016) [160] further demonstrated the use of pre-assembled Cas9-RNA ribonucleoproteins (RNPs) for successfully mutating the same four loci and eliminating the possibility of binary vector genomic integration. In addition, RNP's editing efficiency was approximately equal to the plasmid approach, whereas the off-target editing was not detectable. A more detailed study measuring off-target mutations in maize showed that the frequency of imprecise edits is negligible in comparison to the existing variation being naturally generated in the genome during the conventional breeding [161]. 
Table 1. Transgenic six-stacked maize varieties in commercial use *.

\begin{tabular}{|c|c|c|c|c|c|c|c|}
\hline ISAAA Event & Code (Unique Identifier) & Trade Name & Herbicide Tolerance & Insect Resistance & Drought Tolerance & Modified Starch & Selectable Marker \\
\hline $\begin{array}{c}3272 \times \text { Bt11 } \times \\
59,122 \times \text { MIR604 } \times \\
\text { TC1507 } \times \text { GA21 }\end{array}$ & $\begin{array}{l}\text { SYN-E3272-5 } \times \text { SYN-BTØ11-1 } \times \\
\text { DAS-59122-7 } \times \text { SYN-IR6Ø4-5 } \\
\text { DAS-Ø15Ø7-1 } \times \text { MON-ØØØ21-9 }\end{array}$ & not available & $\begin{array}{l}\text { 1. glyphosate (mepsps) } \\
\text { 2. glufosinate (pat) }\end{array}$ & $\begin{array}{l}\text { 1. Cry1Ab delta-endotoxin }(c r y 1 A b) \\
\text { 2. Cry34Ab1 detta-endotoxin }(c r y 34 A b 1) \\
\text { 3. Cry35Ab1 delta-endotoxin }(r r y 35 \mathrm{Ab} 1) \\
\text { 4. modified Cry3A delta-endotoxin }(m c r y 3 A) \\
\text { 5. modified Cry1F protein (cry1Fa2) }\end{array}$ & none & $\begin{array}{l}\text { 1. thermostable } \\
\alpha \text {-amylase } \\
\text { aa (amy797E) }\end{array}$ & $\begin{array}{l}\text { 1. phosphomannose } \\
\text { aaisomerase (pmi) }\end{array}$ \\
\hline $\begin{array}{c}3272 \times \text { Bt11 } \times \\
\text { MIR604 } \times \text { TC1507 } \\
\times 5307 \times \text { GA21 }\end{array}$ & $\begin{array}{l}\text { SYN-E3272-5 } \times \text { SYN-BTØ11-1 } \times \\
\text { SYN-IR6Ø4-5 } \times \text { DAS-Ø15Ø7-1 } \times \\
\text { SYN-Ø53Ø7-1 } \times \text { MON-ØØØ21-9 }\end{array}$ & not available & $\begin{array}{l}\text { 1. glyphosate (mepsps) } \\
\text { 2. glufosinate (pat) }\end{array}$ & $\begin{array}{l}\text { 1. Cry1Ab delta-endotoxin }(\text { cry } 1 \mathrm{Ab}) \\
\text { 2. modified Cry3A delta-endotoxin }(m c r y 3 A) \\
\text { 3. modified Cry1F protein }(\mathrm{cry} 1 \mathrm{Fa} 2) \\
\text { 4. synthetic form of Cry3A and Cry1Ab } \\
\text { (ecry3.1Ab) }\end{array}$ & none & $\begin{array}{c}\text { 1. thermostable } \\
\alpha \text {-amylase } \\
\text { aa(amy797E) }\end{array}$ & $\begin{array}{l}\text { 1. phosphomannose } \\
\text { ccisomerase (pmi) }\end{array}$ \\
\hline $\begin{array}{l}5307 \times \text { MIR604 } \times \\
\text { Bt11 } \times \text { TC1507 } \times \\
\text { GA21 } \times \text { MIR162 }\end{array}$ & $\begin{array}{l}\text { SYN-Ø53Ø7-1 × SYN-IR6 64-5 } \times \\
\text { SYN-BTØ11-1 × DAS-Ø15Ø7-1 } \\
\text { MON-ØØØ21-9 } \times \text { SYN-IR162-4 }\end{array}$ & $\begin{array}{c}\text { Agrisure }_{5222}^{\circledR} \text { Duracade }^{\mathrm{TM}} \\
\end{array}$ & $\begin{array}{l}\text { 1. glyphosate (mepsps) } \\
\text { 2. glufosinate (pat) }\end{array}$ & $\begin{array}{l}\text { 1. Cry1Ab delta-endotoxin (cry1Ab) } \\
\text { 2. modified Cry3A delta-endotoxin }(m c r y 3 A) \\
\text { 3. modified Cry1F protein }(\text { cry1Fa2) } \\
\text { 4. chimeric Cry3A-Cry1Ab delta (ecry3.1Ab) } \\
\text { 5. vegetative insecticidal protein (vip3Aa20) }\end{array}$ & none & & $\begin{array}{l}\text { 1. phosphomannose } \\
\text { aaisomerase (pmi) }\end{array}$ \\
\hline $\begin{array}{l}\text { Bt11 } \times \text { MIR162 } \times \\
\text { MIR604 } \times \\
\text { MON89034 } \times 5307 \\
\times \text { GA21 }\end{array}$ & $\begin{array}{l}\text { SYN-BTØ11-1 × SYN-IR162-4 } \times \\
\text { SYN-IR6Ø4-5 × MON-89Ø34-3 } \times \\
\text { SYN-Ø53Ø7-1 × MON-ØØØ21-9 }\end{array}$ & not available & $\begin{array}{l}\text { 1. glyphosate (mepsps) } \\
\text { 2. glufosinate (pat) }\end{array}$ & $\begin{array}{l}\text { 1. Cry1Ab delta-endotoxin (cry1Ab) } \\
\text { 2. modified Cry3A delta-endotoxin }(m c r y 3 A) \\
\text { 3. vegetative insecticidal protein (vip3Aa20) } \\
\text { 4. Cry2Ab delta-endotoxin (cry2Ab2) } \\
\text { 5. chimeric Cry1Ab-Cry1F-Cry1Ac } \\
\text { (cry1A.105) } \\
\text { 6. chimeric Cry3A-Cry1Ab delta (ecry3.1Ab) }\end{array}$ & none & & none \\
\hline $\begin{array}{l}\text { MON87427 } \times \\
\text { MON89034 } \\
\text { MON810 } \times \text { MIR162 } \\
\times \text { MON84711 } \\
\text { MON87419 }\end{array}$ & $\begin{array}{c}\text { MON-87427-7 } \times \text { MON-89Ø34-3 } \times \\
\text { MON-ØØ81Ø-6 } \times \text { SYN-IR162-4 } \\
\times \text { MON-87411-9 } \times \text { MON87419-8 }\end{array}$ & not available & $\begin{array}{l}\text { 1. glyphosate (cp4 epsps) } \\
\text { 2. glufosinate (pat) } \\
\text { 3. dicamba }(d m o)\end{array}$ & $\begin{array}{l}\text { 1. Cry1Ab delta-endotoxin (cry1Ab) } \\
\text { 2. vegetative insecticidal protein (vip3Aa20) } \\
\text { 3. Cry2Ab delta-endotoxin (Cry2Ab2) } \\
\text { 4. chimeric Cry1Ab-Cry1F-Cry1Ac } \\
\text { (cry1A.105) } \\
\text { 5. Cry3Bb1 delta endotoxin (cry3Bb1) }\end{array}$ & none & & $\begin{array}{l}\text { 1. glyphosate oxidase } \\
\text { aa(gox } 447) \\
\text { 2. neomycin } \\
\text { phosphotransferase } \\
\text { aa(nptII) } \\
\text { 3. phosphomannose } \\
\text { aaisomerase (pmi) }\end{array}$ \\
\hline $\begin{array}{c}\text { MON87427 } \times \\
\text { MON87460 } \\
\text { MON89034 } \\
\text { TC1507 } \times \\
\text { MON87411 } \times 59122\end{array}$ & $\begin{array}{c}\text { MON-87427-7 } \times \text { MON-8746Ø-4 } \times \\
\text { MON-89Ø34-3 } \times \text { DAS-Ø15Ø7-1 } \\
\times \text { MON-87411-9 } \times \text { DAS-59122-7 }\end{array}$ & not available & $\begin{array}{l}\text { 1. glyphosate (cp4 epspss) } \\
\text { 2. glufosinate (pat) }\end{array}$ & $\begin{array}{l}\text { 1. Cry1F delta-endotoxin (cry1F) } \\
\text { 2. Cry34Ab1 delta-endotoxin (cry34Ab1) } \\
\text { 3. Cry3bb1 delta endotoxin (cry34Bb1) } \\
\text { 4. Cry2Ab delta-endotoxin (cry2Ab2) } \\
\text { 5. chimeric Cry1Ab-Cry1F-Cry1Ac } \\
\text { (cry1A.105) } \\
\text { 6. Cry3Bb1 delta endotoxin (cry3Bb1) } \\
\text { 7. ds RNA (dvsn7) }\end{array}$ & $\begin{array}{l}\text { 1. cold shock } \\
\text { protein B (cspB) }\end{array}$ & & none \\
\hline $\begin{array}{l}\text { MON87427 } \times \\
\text { MON89034 } \\
\text { TC1507 } \times \\
\text { MON87411 } \times \\
59,122 \times \text { DAS40278 }\end{array}$ & $\begin{array}{c}\text { MON-87427-7 } \times \text { MON-89Ø34-3 } \times \\
\text { DAS-Ø15Ø7-1 } \times \text { MON-87411-9 } \times \\
\text { DAS-59122-7 } \times \text { DAS-4Ø278-9 }\end{array}$ & $\underset{\text { Enlist }^{\mathrm{TM}}}{\text { SmartStax }}$ & $\begin{array}{l}\text { 1. glyphosate (cp4 epsps) } \\
\text { 2. glufosinate (pat) } \\
\text { 3. 2,4-D (aad-1) }\end{array}$ & $\begin{array}{l}\text { 1. Cry1F delta-endotoxin (cry1F) } \\
\text { 2. Cry34Ab1 delta-endotoxin ( }(r y 34 A b 1) \\
\text { 3. Cry35Ab1 delta endotoxin ( }(c r y 35 A b 1) \\
\text { 4. Cry2Ab delta-endotoxin }(c r y 2 A b 2) \\
\text { 5. chimeric Cry1Ab-Cry1F-Cry1Ac } \\
\text { (cry1A.105) } \\
\text { 6. Cry3Bb1 delta endotoxin (cry3Bb1) } \\
\text { 7. ds RNA (dvsnf7) }\end{array}$ & none & & none \\
\hline
\end{tabular}


Table 1. Cont.

\begin{tabular}{|c|c|c|c|c|c|c|c|}
\hline ISAAA Event & Code (Unique Identifier) & Trade Name & Herbicide Tolerance & Insect Resistance & Drought Tolerance & Modified Starch & Selectable Marker \\
\hline $\begin{array}{l}\text { MON87427 } \times \\
\text { MON89034× } \\
\text { TC1507 } \times \\
\text { MON87411 } \\
59,122 \times \\
\text { MON87419 }\end{array}$ & $\begin{array}{c}\text { MON-87427-7 } \times \text { MON-89Ø34-3 } \\
\text { DAS-Ø15Ø7-1 } \times \text { MON-87411-9 } \\
\text { DAS-59122-7 } \times \text { MON87419-8 }\end{array}$ & not available & $\begin{array}{l}\text { 1. glyphosate (cp4 epsps), } \\
2 \text { cassettes } \\
\text { 2. glufosinate (pat), } \\
3 \text { cassettes } \\
\text { 3. dicamba }(d m o)\end{array}$ & $\begin{array}{l}\text { 1. modified Cry1F protein (cry1Fa2) } \\
\text { 2. Cry34Ab1 delta-endotoxin (cry34Ab1) } \\
\text { 3. Cry35Ab1 delta endotoxin (cry35Ab1) } \\
\text { 4. Cry2Ab delta-endotoxin (cry2Ab2) } \\
\text { 5. chimeric Cry1Ab-Cry1F-Cry1Ac } \\
\text { (cry1A.105) } \\
\text { 6. Cry3Bb1 delta endotoxin (cry3Bb1) } \\
\text { 7. ds RNA (dvsnf7) }\end{array}$ & none & & none \\
\hline
\end{tabular}

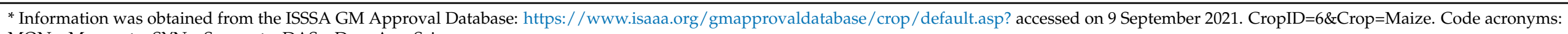
MON_Monsanto, SYN—Syngenta, DAS—Dow AgroSciences. 
Another example was the editing of ARGOS8, a negative regulator of the ethylene response, which was sufficient to increase the maize grain yield under drought stress conditions [162]. By using a CRISPR/Cas9 homology-directed repair (HDR), the maize promoter GOS2 was inserted downstream of the native ARGOS8 promoter, leading to moderate levels of constitutive expression and leading to better performance under drought conditions. Genome editing also enables the easy manipulation of elite hybrid parental lines, bypassing backcross breeding during the introgression of recessive mutant alleles. In particular, a recent study demonstrated successful editing of the waxy (Wx) locus, leading to high endosperm amylopectin content, which is necessary for industrial starch production [163]. Another example is the inactivation of two aldehyde dehydrogenase genes in maize ( $\mathrm{ZmBADH} 2 a$ and $\mathrm{ZmBADH} 2 b)$, leading to the creation of the world's first aromatic maize [147]. Besides inducing a small modification at single loci, it was recently demonstrated that big chromosomal rearrangements in maize are also possible with the CRISPR/Cas9 system. A targeted 75.5-Mb pericentric inversion was performed on maize chromosome 2 in order to re-open previously inaccessible chromosome regions for recombination [164].

Base editing and prime editing $[165,166]$ are two novel gene editing techniques that do not induce DNA double strand brakes (DSB) and INDELs (insertions/deletions). Both have been applied in maize recently. For example, maize protoplast and immature maize embryos were transformed with a cytidine deaminase attached to an inactive nCas9 variant targeting the $\mathrm{ZmCENH3}$ locus in order to obtain edits necessary to generate a haploid-inducing phenotype. Monoallelic or biallelic $\mathrm{C}$ to $\mathrm{T}$ conversions were reported in both protoplasts and immature embryos [167]. Another example was the generation of sulfonylurea-resistant maize plants using a CRISPR/Cas9 nickase-cytidine deaminase (CT-nCas9) fused to an uracil DNA glycosylase inhibitor (UGI). The nickase induces one DNA nick and deaminates $C$ to $U$, whereas a UGI prevents the repair of the newly generated uracil. Two loci, ZmALS1 (acetoacetate synthase) and ZmALS2, were successfully edited, though with somewhat lower efficiencies for ZmALS2. Nevertheless, sulfonylurea resistant plants were obtained and the transgene itself was crossed out. The edited plants could withstand sulfonylurea concentrations 5-15 times the recommended upper limit. Another group achieved double mutants in the same two ALS genes, but this time using prime editing and reported an improvement in the editing efficiencies compared to the published pioneering work in rice [168]. Recently, to test the precision of prime editing in plants, off-target modifications or genomic pegRNA integrations (prime editing gRNA) were measured. Such events were reported to be negligible or nonexistent [169].

Another important development in improving the breeding speed of multi-stress tolerant maize variants in the future will be the combination of the genome editing and haploid induction. In this approach, named HI-Edit (haploid induction editing technology) or IMGE (Haploid-Inducer Mediated Genome Editing), the haploid inducer line is also the editor line with an integrated Cas9-gRNA expression cassette. After the HI inducer cross, the desired genome edit takes place in the zygote, followed by a uniparental genome elimination (haploidization). The product is a genome edited haploid that can be converted to a double haploid (DH) after cytostatic, i.e., colchicine, application [170,171]. This strategy is faster at generating edits to elite breeding lines, circumventing selfing or backcrossing if necessary for eliminating the transgene encoding the editing machinery.

To conclude, the multiple-stress tolerant maize varieties already in use are designed to primarily be weed protected (herbicide tolerance) and insect resistant ( $B t$ toxins and RNAi). Only a minority of these varieties are also drought resistant, but this trait is expected to be introduced more frequently in new elite varieties. Nevertheless, a lot of other stress types have to be addressed in order to make agriculture more resilient to the consequences of climate change. Molecular tools and breeding techniques for achieving this goal seem to be at hand. A far more unpredictable challenge in reaching these goals will be public mistrust and politics [172]. 


\section{Conclusions and Prospects for the Future}

Understanding the genetic mechanism on individual and multiple stress tolerance will be limited unless physiological and molecular mechanisms of plant responses to individual stresses and stress combinations, consisting of both shared and unique responses $[173,174]$, can be elucidated. Thus, an integrated framework is needed for this challenging task. Bailey-Serres et al. (2019) [175] presented the integrative potential of plant sciences exploring emerging strategies for enhancing sustainable crop production that could be also applied on multiple-stress tolerance. In this paper, we focus on a quantitative genetic approach based on naturally occurring variation and genetic engineering, as a result of integrating the meta-analysis of existing plant omics data [49]. However, the opportunities for enhancing multiple-stress tolerance in crops are much broader, comprising an investigation of beneficial soil and leaf microbiome, small-molecule delivery and the use of sensors (cellular, organ canopy and remote) [175], indicating the complexity of the topic. Research in Arabidopsis shows that six stress combinations [176], but already two stress combinations [177], are lethal, even when each single stress is relatively mild. This makes multiple stress tolerance a rather difficult goal to achieve. Nevertheless, systemic ROS signaling was identified as the crucial switch for integrating responses to at least abiotic stress combinations. Altogether, modern research on the genetic improvement of multiple stress tolerance should be more connected to molecular phenotype modeling by using classical crop modeling [178] or machine learning approaches [179,180]. Machine learning is applied in studies of plant-pathogen interaction including disease monitoring, the discovery of gene regulatory networks and genomic selection for disease resistance [181]. The category of unsupervised machine learning is of special interest, whereas there is no specification about the outcome in the data set with clustering and "feature" extraction [182]. It is a new paradigm where traditional stress-related traits could be substituted by synthetic features possibly more related to multiple-stress conditions that could be important for investigating crop resilience under climate change.

Author Contributions: Conceptualization, N.M. and D.Š.; writing-original draft preparation, N.M., J.A.D., L.V. and D.Š.; writing-review and editing, N.M., J.A.D., V.C. and D.Š.; supervision, V.C.; funding acquisition, D.Š. All authors have read and agreed to the published version of the manuscript.

Funding: This research was funded by the EU project "Biodiversity and Molecular Plant Breeding", grant number KK.01.1.1.01.0005, of the Centre of Excellence for Biodiversity and Molecular Plant Breeding (CroP-BioDiv), Zagreb, Croatia.

Institutional Review Board Statement: Not applicable.

Informed Consent Statement: Not applicable.

Conflicts of Interest: The authors declare no conflict of interest.

\section{References}

1. Campos, H.; Cooper, M.; Habben, J.E.; Edmeades, G.O.; Schussler, J.R. Improving Drought Tolerance in Maize: A View from Industry. Field Crops Res. 2004, 90, 19-34. [CrossRef]

2. Duvick, D. The Contribution of Breeding to Yield Advances in Maize (Zea Mays L.). Adv. Agron. 2005, 86, 83-145. [CrossRef]

3. Tollenaar, M.; Lee, E.; Tollenaar, M.; Lee, E.A. Yield Potential, Yield Stability and Stress Tolerance in Maize. Field Crops Res. 2002, 75, 161-169. [CrossRef]

4. Ribaut, J.-M.; Betran, J.; Monneveux, P.; Setter, T. Drought Tolerance in Maize. In Handbook of Maize: Its Biology; Bennetzen, J.L., Hake, S.C., Eds.; Springer: New York, NY, USA, 2009; pp. 311-344. ISBN 978-0-387-79418-1.

5. Harrison, M.T.; Tardieu, F.; Dong, Z.; Messina, C.D.; Hammer, G.L. Characterizing Drought Stress and Trait Influence on Maize Yield under Current and Future Conditions. Glob. Change Biol. 2014, 20, 867-878. [CrossRef] [PubMed]

6. Deryng, D.; Conway, D.; Ramankutty, N.; Price, J.; Warren, R. Global Crop Yield Response to Extreme Heat Stress under Multiple Climate Change Futures. Environ. Res. Lett. 2014, 9, 034011. [CrossRef]

7. Prasad, T.K.; Anderson, M.D.; Martin, B.A.; Stewart, C.R. Evidence for Chilling-Induced Oxidative Stress in Maize Seedlings and a Regulatory Role for Hydrogen Peroxide. Plant Cell 1994, 6, 65-74. [CrossRef] [PubMed]

8. Farooq, M.; Aziz, T.; Wahid, A.; Lee, D.; Siddique, K. Chilling Tolerance in Maize: Agronomic and Physiological Approaches. Crop Pasture Sci. 2009, 60, 501-516. [CrossRef] 
9. Leipner, J.; Stamp, P. Chilling Stress in Maize Seedlings. In Handbook of Maize: Its Biology; Bennetzen, J.L., Hake, S.C., Eds.; Springer: New York, NY, USA, 2009; pp. 291-310, ISBN 978-0-387-79418-1.

10. Subbaiah, C.C.; Sachs, M.M. Responses to Oxygen Deprivation and Potential for Enhanced Flooding Tolerance in Maize. In Handbook of Maize: Its Biology; Bennetzen, J.L., Hake, S.C., Eds.; Springer: New York, NY, USA, 2009; pp. 345-365, ISBN 978-0-387-79418-1.

11. Redinbaugh, M.G.; Pratt, R.C. Virus Resistance. In Handbook of Maize: Its Biology; Bennetzen, J.L., Hake, S.C., Eds.; Springer: New York, NY, USA, 2009; pp. 251-270, ISBN 978-0-387-79418-1.

12. Balint-Kurti, P.J.; Johal, G.S. Maize Disease Resistance. In Handbook of Maize: Its Biology; Bennetzen, J.L., Hake, S.C., Eds.; Springer New York: New York, NY, 2009; pp. 229-250, ISBN 978-0-387-79417-4.

13. Badu-Apraku, B.; Akinwale, R. Cultivar Evaluation and Trait Analysis of Tropical Early Maturing Maize under Strigainfested and Strigafree Environments. Field Crops Res. 2011, 1, 186-194. [CrossRef]

14. McMullen, M.; Frey, M.; Degenhardt, J. Genetics and Biochemistry of Insect Resistance in Maize. In Handbook Maize; Springer: Berlin, Germany, 2008; pp. 271-289.

15. Blondel, C.; Khelalfa, F.; Reynaud, S.; Fauvelle, F.; Raveton, M. Effect of Organochlorine Pesticides Exposure on the Maize Root Metabolome Assessed Using High-Resolution Magic-Angle Spinning (1)H NMR Spectroscopy. Environ. Pollut. Barking Essex 2016, 214, 539-548. [CrossRef]

16. Matters, G.L.; Scandalios, J.G. Effect of the Free Radical-Generating Herbicide Paraquat on the Expression of the Superoxide Dismutase (Sod) Genes in Maize. Biochim. Biophys. Acta 1986, 882, 29-38. [CrossRef]

17. Nemat Alla, M.M.; Badawi, A.-H.M.; Hassan, N.M.; El-Bastawisy, Z.M.; Badran, E.G. Herbicide Tolerance in Maize Is Related to Increased Levels of Glutathione and Glutathione-Associated Enzymes. Acta Physiol. Plant. 2008, 30, 371-379. [CrossRef]

18. Pál, M.; Horváth, E.; Janda, T.; Páldi, E.; Szalai, G. Physiological Changes and Defense Mechanisms Induced by Cadmium Stress in Maize. J. Plant Nutr. Soil Sci. 2006, 169, 239-246. [CrossRef]

19. Krill, A.M.; Kirst, M.; Kochian, L.V.; Buckler, E.S.; Hoekenga, O.A. Association and Linkage Analysis of Aluminum Tolerance Genes in Maize. PLoS ONE 2010, 5, e9958. [CrossRef]

20. Geiger, H.H. Agronomic Traits and Maize Modifications: Nitrogen Use Efficiency. In Handbook of Maize: Its Biology; Bennetzen, J.L., Hake, S.C., Eds.; Springer: New York, NY, USA, 2009; pp. 405-417, ISBN 978-0-387-79418-1.

21. Calderón-Vázquez, C.; Alatorre-Cobos, F.; Simpson-Williamson, J.; Herrera-Estrella, L. Maize Under Phosphate Limitation. In Handbook of Maize: Its Biology; Bennetzen, J.L., Hake, S.C., Eds.; Springer New York: New York, NY, USA, 2009; pp. 381-404, ISBN 978-0-387-79417-4.

22. Gunes, A.; Inal, A.; Alpaslan, M.; Cicek, N.; Guneri, E.; Eraslan, F.; Guzelordu, T. Effects of Exogenously Applied Salicylic Acid on the Induction of Multiple Stress Tolerance and Mineral Nutrition in Maize (Zea Mays L.). Arch. Agron. Soil Sci. 2005, 51, 687-695. [CrossRef]

23. Pandey, S.; Ceballos, H.; Magnavaca, R.; Bahía Filho, A.F.C.; Duque-Vargas, J.; Vinasco, L.E. Genetics of Tolerance to Soil Acidity in Tropical Maize. Crop Sci. 1994, 34, 1511-1514. [CrossRef]

24. Ngoune Tandzi, L.; Mutengwa, C.S.; Ngonkeu, E.L.M.; Gracen, V. Breeding Maize for Tolerance to Acidic Soils: A Review. Agronomy 2018, 8, 84. [CrossRef]

25. Zhao, C.; Liu, B.; Piao, S.; Wang, X.; Lobell, D.B.; Huang, Y.; Huang, M.; Yao, Y.; Bassu, S.; Ciais, P.; et al. Temperature Increase Reduces Global Yields of Major Crops in Four Independent Estimates. Proc. Natl. Acad. Sci. USA 2017, 114, 9326-9331. [CrossRef] [PubMed]

26. Challinor, A.J.; Watson, J.; Lobell, D.B.; Howden, S.M.; Smith, D.R.; Chhetri, N. A Meta-Analysis of Crop Yield under Climate Change and Adaptation. Nat. Clim. Change 2014, 4, 287-291. [CrossRef]

27. Easterling, W.E.; Aggarwal, P.K.; Batima, P.; Brander, K.; Lin, E.; Howden, S.; Kirilenko, A.; Morton, J.; Soussana, J.-F.; Schmidhuber J.; et al. Food, fibre and forest products; Cambridge University Press: Cambridge, UK, 2007; pp. 273-313, ISBN 978-0-521-70597-4.

28. Rosenzweig, C.; Elliott, J.; Deryng, D.; Ruane, A.C.; Müller, C.; Arneth, A.; Boote, K.J.; Folberth, C.; Glotter, M.; Khabarov, N.; et al. Assessing Agricultural Risks of Climate Change in the 21st Century in a Global Gridded Crop Model Intercomparison. Proc. Natl. Acad. Sci. USA 2014, 111, 3268-3273. [CrossRef]

29. Heisey, P.; Edmeades, G. Cimmyt 1997/98 World Maize Facts and Trends; Maize Production in Drought-Stressed Environments: Technical Options and Research Resource Allocation. CIMMYT Int. Maize Wheat Improv. Cent. Facts Trends Overview Outlook 1999, 9369. [CrossRef]

30. Bänziger, M.; Araus, J.-L. Recent Advances in Breeding Maize for Drought and Salinity Stress Tolerance. In Advances in Molecular Breeding Toward Drought and Salt Tolerant Crops; Jenks, M.A., Hasegawa, P.M., Jain, S.M., Eds.; Springer: Dordrecht, Netherlands, 2007; pp. 587-601, ISBN 978-1-4020-5578-2.

31. Jiang, P.; Cai, F.; Zhao, Z.-Q.; Meng, Y.; Gao, L.-Y.; Zhao, T.-H. Physiological and Dry Matter Characteristics of Spring Maize in Northeast China under Drought Stress. Water 2018, 10, 1561. [CrossRef]

32. Aslam, M.; Maqbool, M.A.; Cengiz, R. Drought Stress in Maize (Zea Mays L.): Effects, Resistance Mechanism, Global Achievements and Biological Strategies for Improvement; Springer Briefs in Agriculture; Springer: Cham, Switzerland, 2015; ISBN 978-3-319-25442-5.

33. Buhiniček, I.; Kaučić, D.; Kozić, Z.; Jukić, M.; Gunjača, J.; Šarčević, H.; Stepinac, D.; Šimić, D. Trends in Maize Grain Yields across Five Maturity Groups in a Long-Term Experiment with Changing Genotypes. Agriculture 2021, 11, 887. [CrossRef] 
34. Lobell, D.B.; Hammer, G.L.; McLean, G.; Messina, C.; Roberts, M.J.; Schlenker, W. The Critical Role of Extreme Heat for Maize Production in the United States. Nat. Clim. Change 2013, 3, 497-501. [CrossRef]

35. Crafts-Brandner, S.J.; Salvucci, M.E. Sensitivity of Photosynthesis in a C4 Plant, Maize, to Heat Stress. Plant Physiol. 2002, 129, 1773-1780. [CrossRef] [PubMed]

36. Cicchino, M.; Edreira, J.I.R.; Uribelarrea, M.; Otegui, M.E. Heat Stress in Field-Grown Maize: Response of Physiological Determinants of Grain Yield. Crop Sci. 2010, 50, 1438-1448. [CrossRef]

37. Hasanuzzaman, M.; Nahar, K.; Alam, M.M.; Roychowdhury, R.; Fujita, M. Physiological, Biochemical, and Molecular Mechanisms of Heat Stress Tolerance in Plants. Int. J. Mol. Sci. 2013, 14, 9643-9684. [CrossRef] [PubMed]

38. Lagriffoul, A.; Mocquot, B.; Mench, M.; Vangronsveld, J. Cadmium Toxicity Effects on Growth, Mineral and Chlorophyll Contents, and Activities of Stress Related Enzymes in Young Maize Plants (Zea Mays L.). Plant Soil 1998, 200, 241-250. [CrossRef]

39. AbdElgawad, H.; Zinta, G.; Hamed, B.A.; Selim, S.; Beemster, G.; Hozzein, W.N.; Wadaan, M.A.M.; Asard, H.; Abuelsoud, W. Maize Roots and Shoots Show Distinct Profiles of Oxidative Stress and Antioxidant Defense under Heavy Metal Toxicity. Environ. Pollut. Barking Essex 1987 2020, 258, 113705. [CrossRef]

40. Franić, M.; Galić, V. As, Cd, Cr, Cu, Hg: Physiological Implications and Toxicity in Plants. Plant Met. Funct. Omics 2019, 209-253. [CrossRef]

41. Ciampitti, I.A.; Vyn, T.J. A Comprehensive Study of Plant Density Consequences on Nitrogen Uptake Dynamics of Maize Plants from Vegetative to Reproductive Stages. Field Crops Res. 2011, 121, 2-18. [CrossRef]

42. Sher, A.; Khan, A.; Cai, L.J.; Irfan Ahmad, M.; Asharf, U.; Jamoro, S.A. Response of Maize Grown Under High Plant Density; Performance, Issues and Management-A Critical Review. Adv. Crop Sci. Technol. 2017. [CrossRef]

43. Nguyen, D.; Rieu, I.; Mariani, C.; van Dam, N.M. How Plants Handle Multiple Stresses: Hormonal Interactions Underlying Responses to Abiotic Stress and Insect Herbivory. Plant Mol. Biol. 2016, 91, 727-740. [CrossRef] [PubMed]

44. Parsons, M. Biotic and Abiotic Factors Associated with Fusarium Ear Rot of Maize Caused by Fusarium Verticillioides. Grad. Theses Diss. 2008. [CrossRef]

45. Ivezić, M.; Raspudić, E.; Brmež, M.; Majić, I.; Brkić, I.; Tollefson, J.J.; Bohn, M.; Hibbard, B.E.; Šimić, D. A Review of Resistance Breeding Options Targeting Western Corn Rootworm (Diabrotica Virgifera Virgifera LeConte). Agric. For. Entomol. 2009, 11, 307-311. [CrossRef]

46. Meissle, M.; Romeis, J.; Bigler, F. Bt Maize and Integrated Pest Management-A European Perspective. Pest Manag. Sci. 2011, 67, 1049-1058. [CrossRef]

47. Galić, V.; Šimić, D.; Franić, M.; Brkić, A.; Jambrović, A.; Brkić, J.; Ledenčan, T. Analysis of Fusarium Ear Rot and Fumonisin Contamination in Testcrosses of a Maize Biparental Population. Crop Breed. Appl. Biotechnol. 2019, 19, 40-46. [CrossRef]

48. Campos-Bermudez, V.A.; Fauguel, C.M.; Tronconi, M.A.; Casati, P.; Presello, D.A.; Andreo, C.S. Transcriptional and Metabolic Changes Associated to the Infection by Fusarium Verticillioides in Maize Inbreds with Contrasting Ear Rot Resistance. PLoS ONE 2013, 8, e61580. [CrossRef]

49. Mahalingam, R. Consideration of Combined Stress: A Crucial Paradigm for Improving Multiple Stress Tolerance in Plants. In Combined Stresses in Plants: Physiological, Molecular, and Biochemical Aspects; Mahalingam, R., Ed.; Springer International Publishing: Cham, Switzerland, 2015; pp. 1-25. ISBN 978-3-319-07899-1.

50. Rivero, R.M.; Mittler, R.; Blumwald, E.; Zandalinas, S.I. Developing Climate-Resilient Crops: Improving Plant Tolerance to Stress Combination. Plant J. 2021. [CrossRef]

51. Mittler, R. Abiotic Stress, the Field Environment and Stress Combination. Trends Plant Sci. 2006, 11, 15-19. [CrossRef]

52. Suzuki, N.; Rivero, R.M.; Shulaev, V.; Blumwald, E.; Mittler, R. Abiotic and Biotic Stress Combinations. New Phytol. 2014, 203, 32-43. [CrossRef]

53. Zandalinas, S.I.; Fritschi, F.B.; Mittler, R. Global Warming, Climate Change, and Environmental Pollution: Recipe for a Multifactorial Stress Combination Disaster. Trends Plant Sci. 2021, 26, 588-599. [CrossRef]

54. Cairns, J.E.; Crossa, J.; Zaidi, P.H.; Grudloyma, P.; Sanchez, C.; Araus, J.L.; Thaitad, S.; Makumbi, D.; Magorokosho, C.; Bänziger, M.; et al. Identification of Drought, Heat, and Combined Drought and Heat Tolerant Donors in Maize. Crop. Breed. Genet. 2013, 4 1335-1346. [CrossRef]

55. Meseka, S.; Menkir, A.; Bossey, B.; Mengesha, W. Performance Assessment of Drought Tolerant Maize Hybrids under Combined Drought and Heat Stress. Agronomy 2018, 8, 274. [CrossRef] [PubMed]

56. Nelimor, C.; Badu-Apraku, B.; Tetteh, A.Y.; N'guetta, A.S.P. Assessment of Genetic Diversity for Drought, Heat and Combined Drought and Heat Stress Tolerance in Early Maturing Maize Landraces. Plants 2019, 8, 518. [CrossRef]

57. Chiuta, N.E.; Mutengwa, C.S. Combining Ability of Quality Protein Maize Inbred Lines for Yield and Morpho-Agronomic Traits under Optimum as Well as Combined Drought and Heat-Stressed Conditions. Agronomy 2020, 10, 184. [CrossRef]

58. Nasser, L.M.; Badu-Apraku, B.; Gracen, V.E.; Mafouasson, H.N.A. Combining Ability of Early-Maturing Yellow Maize Inbreds under Combined Drought and Heat Stress and Well-Watered Environments. Agronomy 2020, 10, 1585. [CrossRef]

59. Nelimor, C.; Badu-Apraku, B.; Tetteh, A.Y.; Garcia-Oliveira, A.L.; N'guetta, A.S.-P. Assessing the Potential of Extra-Early Maturing Landraces for Improving Tolerance to Drought, Heat, and Both Combined Stresses in Maize. Agronomy 2020, 10, 318. [CrossRef]

60. Tesfaye, K.; Kruseman, G.; Cairns, J.E.; Zaman-Allah, M.; Wegary, D.; Zaidi, P.H.; Boote, K.J.; Rahut, D.; Erenstein, O. Potential Benefits of Drought and Heat Tolerance for Adapting Maize to Climate Change in Tropical Environments. Clim. Risk Manag. 2018, 19, 106-119. [CrossRef] 
61. Mengesha, W.A.; Menkir, A.; Unakchukwu, N.; Meseka, S.; Farinola, A.; Girma, G.; Gedil, M. Genetic Diversity of Tropical Maize Inbred Lines Combining Resistance to Striga Hermonthica with Drought Tolerance Using SNP Markers. Plant Breed. 2017, 136, 338-343. [CrossRef]

62. Annor, B.; Badu-Apraku, B.; Nyadanu, D.; Akromah, R.; Fakorede, M.A.B. Testcross Performance and Combining Ability of Early Maturing Maize Inbreds under Multiple-Stress Environments. Sci. Rep. 2019, 9, 13809. [CrossRef]

63. Prasanna, B.M.; Cairns, J.E.; Zaidi, P.H.; Beyene, Y.; Makumbi, D.; Gowda, M.; Magorokosho, C.; Zaman-Allah, M.; Olsen, M.; Das, A.; et al. Beat the Stress: Breeding for Climate Resilience in Maize for the Tropical Rainfed Environments. TAG Theor. Appl. Genet. Theor. Angew. Genet. 2021, 134, 1729-1752. [CrossRef] [PubMed]

64. Forieri, I.; Hildebrandt, U.; Rost $\tilde{A}_{j} \mathrm{~s}$, M. Salinity Stress Effects on Direct and Indirect Defence Metabolites in Maize. Environ. Exp. Bot. 2016, 122, 68-77. [CrossRef]

65. Block, A.K.; Hunter, C.T.; Sattler, S.E.; Rering, C.; McDonald, S.; Basset, G.J.; Christensen, S.A. Fighting on Two Fronts: Elevated Insect Resistance in Flooded Maize. Plant Cell Environ. 2020, 43, 223-234. [CrossRef] [PubMed]

66. Yang, K.; Zhang, Y.; Zhu, L.; Li, Z.; Deng, B. Omethoate Treatment Mitigates High Salt Stress Inhibited Maize Seed Germination. Pestic. Biochem. Physiol. 2018, 144, 79-82. [CrossRef] [PubMed]

67. Parsons, M.W.; Munkvold, G.P. Associations of Planting Date, Drought Stress, and Insects with Fusarium Ear Rot and Fumonisin B1 Contamination in California Maize. Food Addit. Contam. Part A 2010, 27, 591-607. [CrossRef] [PubMed]

68. Chávez-Arias, C.C.; Ligarreto-Moreno, G.A.; Ramírez-Godoy, A.; Restrepo-Díaz, H. Maize Responses Challenged by Drought, Elevated Daytime Temperature and Arthropod Herbivory Stresses: A Physiological, Biochemical and Molecular View. Front. Plant Sci. 2021, 12, 1512. [CrossRef]

69. Atkinson, N.J.; Urwin, P.E. The Interaction of Plant Biotic and Abiotic Stresses: From Genes to the Field. J. Exp. Bot. 2012, 63, 3523-3543. [CrossRef] [PubMed]

70. Obata, T.; Witt, S.; Lisec, J.; Palacios-Rojas, N.; Florez-Sarasa, I.; Yousfi, S.; Araus, J.L.; Cairns, J.E.; Fernie, A.R. Metabolite Profiles of Maize Leaves in Drought, Heat, and Combined Stress Field Trials Reveal the Relationship between Metabolism and Grain Yield. Plant Physiol. 2015, 169, 2665-2683. [CrossRef] [PubMed]

71. Ayub, M.; Ashraf, M.Y.; Kausar, A.; Saleem, S.; Anwar, S.; Altay, V.; Ozturk, M. Growth and Physio-Biochemical Responses of Maize (Zea Mays L.) to Drought and Heat Stresses. Plant Biosyst.-Int. J. Deal. Asp. Plant Biol. 2021, 155, 535-542. [CrossRef]

72. Mittler, R. Oxidative Stress, Antioxidants and Stress Tolerance. Trends Plant Sci. 2002, 7, 405-410. [CrossRef]

73. Gill, S.S.; Tuteja, N. Reactive Oxygen Species and Antioxidant Machinery in Abiotic Stress Tolerance in Crop Plants. Plant Physiol. Biochem. PPB 2010, 48, 909-930. [CrossRef]

74. Choudhury, F.K.; Rivero, R.M.; Blumwald, E.; Mittler, R. Reactive Oxygen Species, Abiotic Stress and Stress Combination. Plant J. Cell Mol. Biol. 2017, 90, 856-867. [CrossRef]

75. Herb, M.; Gluschko, A.; Schramm, M. Reactive Oxygen Species: Not Omnipresent but Important in Many Locations. Front. Cell Dev. Biol. 2021, 9, 2503. [CrossRef]

76. Sachdev, S.; Ansari, S.A.; Ansari, M.I.; Fujita, M.; Hasanuzzaman, M. Abiotic Stress and Reactive Oxygen Species: Generation, Signaling, and Defense Mechanisms. Antioxidants 2021, 10, 277. [CrossRef] [PubMed]

77. Anjum, S.A.; Tanveer, M.; Hussain, S.; Bao, M.; Wang, L.; Khan, I.; Ullah, E.; Tung, S.A.; Samad, R.A.; Shahzad, B. Cadmium Toxicity in Maize (Zea Mays L.): Consequences on Antioxidative Systems, Reactive Oxygen Species and Cadmium Accumulation. Environ. Sci. Pollut. Res. Int. 2015, 22, 17022-17030. [CrossRef] [PubMed]

78. Jawad Hassan, M.; Ali Raza, M.; Ur Rehman, S.; Ansar, M.; Gitari, H.; Khan, I.; Wajid, M.; Ahmed, M.; Abbas Shah, G.; Peng, Y.; et al. Effect of Cadmium Toxicity on Growth, Oxidative Damage, Antioxidant Defense System and Cadmium Accumulation in Two Sorghum Cultivars. Plants 2020, 9, 1575. [CrossRef] [PubMed]

79. Anjum, S.A.; Ashraf, U.; Tanveer, M.; Khan, I.; Hussain, S.; Shahzad, B.; Zohaib, A.; Abbas, F.; Saleem, M.F.; Ali, I.; et al. Drought Induced Changes in Growth, Osmolyte Accumulation and Antioxidant Metabolism of Three Maize Hybrids. Front. Plant Sci. 2017, 8, 69. [CrossRef] [PubMed]

80. Chugh, V.; Kaur, N.; Grewal, M.S.; Gupta, A.K. Differential Antioxidative Response of Tolerant and Sensitive Maize (Zea Mays L.) Genotypes to Drought Stress at Reproductive Stage. Indian J. Biochem. Biophys. 2013, 50, 150-158. [PubMed]

81. Moharramnejad, S.; Sofalian, O.; Valizadeh, M.; Asghari, A.; Shiri, M.; Ashraf, M. Response of Maize to Field Drought Stress: Oxidative Defense System, Osmolytes' Accumulation and Photosynthetic Pigments. Pak. J. Bot. 2019, 51, 799-807. [CrossRef]

82. Nahar, S.; Vemireddy, L.R.; Sahoo, L.; Tanti, B. Antioxidant Protection Mechanisms Reveal Significant Response in DroughtInduced Oxidative Stress in Some Traditional Rice of Assam, India. Rice Sci. 2018, 25, 185-196. [CrossRef]

83. Sorić, R.; Lončarić, Z.; Kovačević, V.; Brkić, I.; Šimić, D. A Major Gene for Leaf Cadmium Accumulation in Maize (Zea Mays L). In Proceedings of the International Plant Nutrition Colloquium XVI, Sacramento, CA, USA, 26-30 August 2009.

84. Franić, M.; Galić, V.; Lončarić, Z.; Šimić, D. Genotypic Variability of Photosynthetic Parameters in Maize Ear-Leaves at Different Cadmium Levels in Soil. Agronomy 2020, 10, 986. [CrossRef]

85. Antunović Dunić, J.; Franić, M.; Begović, L.; Galić, V.; Mlinarić, S.; Šimić, D.; Cesar, V. Antioxidative response challenged by excess cadmium and water limitation in maize. In Book of Abstracts of 53rd Croatian $\mathcal{E}$ 13th International Symposium on Agriculture, Vodice, Croatia; Faculty of Agriculture, University Josip Juraj Strossmayer: Osijek, Croatia, 2018; pp. 67-68.

86. Turner, N.C. Turgor Maintenance by Osmotic Adjustment: 40 Years of Progress. J. Exp. Bot. 2018, 69, 3223-3233. [CrossRef] 
87. Blum, A. Osmotic Adjustment Is a Prime Drought Stress Adaptive Engine in Support of Plant Production. Plant Cell Environ. 2017, 40, 4-10. [CrossRef]

88. Singh, A.; Sharma, M.K.; Sengar, R.S. Osmolytes: Proline Metabolism in Plants as Sensors of Abiotic Stress. J. Appl. Nat. Sci. 2017, 9, 2079-2092. [CrossRef]

89. Zhao, H.; Guan, J.; Liang, Q.; Zhang, X.; Hu, H.; Zhang, J. Effects of Cadmium Stress on Growth and Physiological Characteristics of Sassafras Seedlings. Sci. Rep. 2021, 11, 9913. [CrossRef]

90. Biswal, B.; Joshi, P.N.; Raval, M.K.; Biswal, U.C. Photosynthesis, a Global Sensor of Environmental Stress in Green Plants: Stress Signalling and Adaptation. Curr. Sci. 2011, 101, 47-56.

91. Tsimilli-Michael, M.; Strasser, R.J. The Energy Flux Theory 35 Years Later: Formulations and Applications. Photosynth. Res. 2013, 117, 289-320. [CrossRef]

92. Kalaji, H.M.; Jajoo, A.; Oukarroum, A.; Brestic, M.; Zivcak, M.; Samborska, I.A.; Cetner, M.D.; Łukasik, I.; Goltsev, V.; Ladle, R.J. Chlorophyll a Fluorescence as a Tool to Monitor Physiological Status of Plants under Abiotic Stress Conditions. Acta Physiol. Plant. 2016, 38, 102. [CrossRef]

93. Strasser, R.J.; Tsimilli-Michael, M.; Srivastava, A. Analysis of the Chlorophyll a Fluorescence Transient. In Chlorophyll a Fluorescence: A Signature of Photosynthesis; Papageorgiou, G.C., Govindjee, Eds.; Advances in Photosynthesis and Respiration; Springer: Dordrecht, The Netherlands, 2004; pp. 321-362. ISBN 978-1-4020-3218-9.

94. Šimić, D.; Lepeduš, H.; Jurković, V.; Antunović, J.; Cesar, V. Quantitative Genetic Analysis of Chlorophyll a Fluorescence Parameters in Maize in the Field Environments. J. Integr. Plant Biol. 2014, 56, 695-708. [CrossRef]

95. Havaux, M.; Lannoye, R. Chlorophyll Fluorescence Induction: A Sensitive Indicator of Water Stress in Maize Plants. Irrig. Sci. 1983, 4, 147-151. [CrossRef]

96. Lepeduš, H.; Brkić, I.; Cesar, V.; Jurković, V.; Antunović, J.; Jambrović, A.; Brkić, J.; Šimić, D. Chlorophyll Fluorescence Analysis of Photosynthetic Performance in Seven Maize Inbred Lines under Water-Limited Conditions. Period. Biol. 2012, 114, 73-76.

97. Sinsawat, V.; Leipner, J.; Stamp, P.; Fracheboud, Y. Effect of Heat Stress on the Photosynthetic Apparatus in Maize (Zea Mays L.) Grown at Control or High Temperature. Environ. Exp Bot 2004, 52, 123-129. [CrossRef]

98. Fracheboud, Y.; Haldimann, P.; Leipner, J.; Stamp, P. Chlorophyll Fluorescence as a Selection Tool for Cold Tolerance of Photosynthesis in Maize (Zea Mays L.). J. Exp. Bot. 1999, 50, 1533-1540. [CrossRef]

99. Baghbani, F.; Lotfi, R.; Moharramnejad, S.; Bandehagh, A.; Roostaei, M.; Rastogi, A.; Kalaji, H.M. Impact of Fusarium Verticillioides on Chlorophyll Fluorescence Parameters of Two Maize Lines. Eur. J. Plant Pathol. 2019, 154, 337-346. [CrossRef]

100. Kopsell, D.A.; Armel, G.R.; Abney, K.R.; Vargas, J.J.; Brosnan, J.T.; Kopsell, D.E. Leaf Tissue Pigments and Chlorophyll Fluorescence Parameters Vary among Sweet Corn Genotypes of Differential Herbicide Sensitivity. Pestic. Biochem. Physiol. 2011, 99, 194-199. [CrossRef]

101. ZHAO, L.; XIE, J.; ZHANG, H.; WANG, Z.; JIANG, H.; GAO, S. Enzymatic Activity and Chlorophyll Fluorescence Imaging of Maize Seedlings (Zea Mays L.) after Exposure to Low Doses of Chlorsulfuron and Cadmium. J. Integr. Agric. 2018, 17, 826-836. [CrossRef]

102. da Silva, A.J.; do Nascimento, C.W.A.; da Silva Gouveia-Neto, A.; da Silva, E.A., Jr. LED-Induced Chlorophyll Fluorescence Spectral Analysis for the Early Detection and Monitoring of Cadmium Toxicity in Maize Plants. Water Air Amp Soil Pollut. 2012, 223, 3527-3534. [CrossRef]

103. Wu, Y.; Qiang, L.; Rong, J.; Wei, C.; Liu, X.L.; Kong, F.L.; Yuan, J.C.; Ke, Y.P.; Shi, H.C. Effect of Low-Nitrogen Stress on Photosynthesis and Chlorophyll Fluorescence Characteristics of Maize Cultivars with Different Low-Nitrogen Tolerances. J. Integr. Agric. 2019, 18, 1246-1256. [CrossRef]

104. Shabala, S.; Shabala, S.; Martynenko, A.; Babourina, O.; Newman, I. Salinity Effect on Bioelectric Activity, Growth, Na+ Accumulation and Chlorophyll Fluorescence of Maize Leaves: A Comparative Survey and Prospects for Screening. Funct. Plant Biol. 1998, 25, 609-616. [CrossRef]

105. Galić, V.; Mazur, M.; Šimić, D.; Zdunić, Z.; Franić, M. Plant Biomass in Salt-Stressed Young Maize Plants Can Be Modelled with Photosynthetic Performance. Photosynthetica 2020, 58, 194-204. [CrossRef]

106. Franić, M.; Mazur, M.; Volenik, M.; Brkić, J.; Brkić, A.; Šimić, D. Effect of Plant Density on Agronomic Traits and Photosynthetic Performance in The Maize Ibm Population. Poljoprivreda 2015, 21, 36-40. [CrossRef]

107. Qu, C.; Liu, C.; Gong, X.; Li, C.; Hong, M.; Wang, L.; Hong, F. Impairment of Maize Seedling Photosynthesis Caused by a Combination of Potassium Deficiency and Salt Stress. Environ. Exp. Bot. 2012, 75, 134-141. [CrossRef]

108. Correia, P.M.P.; da Silva, A.B.; Vaz, M.; Carmo-Silva, E.; Marques da Silva, J. Efficient Regulation of CO2 Assimilation Enables Greater Resilience to High Temperature and Drought in Maize. Front. Plant Sci. 2021, 12, 1505. [CrossRef]

109. Mlinarić, S.; Franić, M.; Galić, V.; Antunović Dunić, J.; Begović, L.; Šimić, D.; Cesar, V. The Effect of Cadmium and Water Stress on Photosynthetic Performance in Maize. In Proceedings of the 53rd Croatian and 13th International Symposium on Agriculture, Vodice, Croatia, 18-23 February 2018; pp. 103-104.

110. Bernardo, R. Reinventing Quantitative Genetics for Plant Breeding: Something Old, Something New, Something Borrowed, Something BLUE. Heredity 2020, 125, 375-385. [CrossRef] [PubMed]

111. Bernardo, R.N. Breeding for Quantitative Traits in Plants; Stemma Press: Woodbury, MN, USA, 2002; ISBN 978-0-9720724-3-4.

112. Wallace, J.G.; Larsson, S.J.; Buckler, E.S. Entering the Second Century of Maize Quantitative Genetics. Heredity 2014, 112, 30-38. [CrossRef] 
113. Kearsey, M.J.; Farquhar, A.G.L. QTL Analysis in Plants; Where Are We Now? Heredity 1998, 80, 137-142. [CrossRef]

114. Korte, A.; Farlow, A. The Advantages and Limitations of Trait Analysis with GWAS: A Review. Plant Methods $2013,9,29$. [CrossRef]

115. Welcome to MaizeGDB. Available online: https://www.maizegdb.org/ (accessed on 8 October 2021).

116. MaizeGDB Locus Search Page. Available online: https:/ /www.maizegdb.org/data_center/locus (accessed on 8 October 2021).

117. Web of Science Core Collection. Web of Science Databases; Clarivate Analytics: Philadelphia, PA, USA, 2019. Available online: https: / / clarivate.com/products/web-of-science/databases/ (accessed on 9 October 2021).

118. Malosetti, M.; Ribaut, J.M.; Vargas, M.; Crossa, J.; van Eeuwijk, F.A. A Multi-Trait Multi-Environment QTL Mixed Model with an Application to Drought and Nitrogen Stress Trials in Maize (Zea Mays L.). Euphytica 2008, 161, 241-257. [CrossRef]

119. Makumburage, G.B.; Stapleton, A. Phenotype Uniformity in Combined-Stress Environments Has a Different Genetic Architecture than in Single-Stress Treatments. Front. Plant Sci. 2011, 2, 12. [CrossRef] [PubMed]

120. Lee, M.; Sharopova, N.; Beavis, W.D.; Grant, D.; Katt, M.; Blair, D.; Hallauer, A. Expanding the Genetic Map of Maize with the Intermated B73 $\times$ Mo17 (IBM) Population. Plant Mol. Biol. 2002, 48, 453-461. [CrossRef]

121. Makumburage, G.B.; Richbourg, H.L.; LaTorre, K.D.; Capps, A.; Chen, C.; Stapleton, A.E. Genotype to Phenotype Maps: Multiple Input Abiotic Signals Combine to Produce Growth Effects via Attenuating Signaling Interactions in Maize. G3 GenesGenomesGenetics 2013, 3, 2195-2204. [CrossRef]

122. Wen, W.; Araus, J.L.; Shah, T.; Cairns, J.; Mahuku, G.; Bänziger, M.; Torres, J.L.; Sánchez, C.; Yan, J. Molecular Characterization of a Diverse Maize Inbred Line Collection and Its Potential Utilization for Stress Tolerance Improvement. Crop Sci. 2011, 51, 2569-2581. [CrossRef]

123. Yuan, Y.; Cairns, J.E.; Babu, R.; Gowda, M.; Makumbi, D.; Magorokosho, C.; Zhang, A.; Liu, Y.; Wang, N.; Hao, Z.; et al. Genome-Wide Association Mapping and Genomic Prediction Analyses Reveal the Genetic Architecture of Grain Yield and Flowering Time Under Drought and Heat Stress Conditions in Maize. Front. Plant Sci. 2019, 9, 1919. [CrossRef]

124. Badji, A.; Kwemoi, D.B.; Machida, L.; Okii, D.; Mwila, N.; Agbahoungba, S.; Kumi, F.; Ibanda, A.; Bararyenya, A.; Solemanegy, M.; et al. Genetic Basis of Maize Resistance to Multiple Insect Pests: Integrated Genome-Wide Comparative Mapping and Candidate Gene Prioritization. Genes 2020, 11, 689. [CrossRef] [PubMed]

125. Hou, F.; Zhou, X.; Liu, P.; Yuan, G.; Zou, C.; Lübberstedt, T.; Pan, G.; Ma, L.; Shen, Y. Genetic Dissection of Maize Seedling Traits in an IBM Syn10 DH Population under the Combined Stress of Lead and Cadmium. Mol. Genet. Genomics MGG 2021, 296, 1057-1070. [CrossRef] [PubMed]

126. Hussain, T.; Tausend, P.; Graham, G.; Ho, J. Registration of IBM2 SYN10 Doubled Haploid Mapping Population of Maize. J. Plant Regist. 2007, 1, 81. [CrossRef]

127. Bubliy, O.A.; Loeschcke, V. Correlated Responses to Selection for Stress Resistance and Longevity in a Laboratory Population of Drosophila Melanogaster. J. Evol. Biol. 2005, 18, 789-803. [CrossRef]

128. Sørensen, J.G.; Kristensen, T.N.; Loeschcke, V. The Evolutionary and Ecological Role of Heat Shock Proteins. Ecol. Lett. 2003, 6, 1025-1037. [CrossRef]

129. Mullineaux, P.; Karpinski, S. Signal Transduction in Response to Excess Light: Getting out of the Chloroplast. Curr. Opin. Plant Biol. 2002, 5, 43-48. [CrossRef]

130. Wisser, R.J.; Kolkman, J.M.; Patzoldt, M.E.; Holland, J.B.; Yu, J.; Krakowsky, M.; Nelson, R.J.; Balint-Kurti, P.J. Multivariate Analysis of Maize Disease Resistances Suggests a Pleiotropic Genetic Basis and Implicates a GST Gene. Proc. Natl. Acad. Sci. USA 2011, 108, 7339-7344. [CrossRef]

131. Kong, X.; Lv, W.; Zhang, D.; Jiang, S.; Zhang, S.; Li, D. Genome-Wide Identification and Analysis of Expression Profiles of Maize Mitogen-Activated Protein Kinase Kinase Kinase. PLoS ONE 2013, 8, e57714. [CrossRef]

132. Moon, H.; Lee, B.; Choi, G.; Shin, D.; Prasad, D.T.; Lee, O.; Kwak, S.-S.; Kim, D.H.; Nam, J.; Bahk, J.; et al. NDP Kinase 2 Interacts with Two Oxidative Stress-Activated MAPKs to Regulate Cellular Redox State and Enhances Multiple Stress Tolerance in Transgenic Plants. Proc. Natl. Acad. Sci. USA 2003, 100, 358-363. [CrossRef]

133. Bernardo, R. Molecular Markers and Selection for Complex Traits in Plants: Learning from the Last 20 Years. Crop Sci. 2008, 48 , 1649-1664. [CrossRef]

134. Cobb, J.N.; Biswas, P.S.; Platten, J.D. Back to the Future: Revisiting MAS as a Tool for Modern Plant Breeding. TAG Theor. Appl. Genet. Theor. Angew. Genet. 2019, 132, 647-667. [CrossRef] [PubMed]

135. Shikha, K.; Shahi, J.P.; Vinayan, M.T.; Zaidi, P.H.; Singh, A.K.; Sinha, B. Genome-Wide Association Mapping in Maize: Status and Prospects. 3 Biotech 2021, 11, 244. [CrossRef]

136. Tuberosa, R.; Salvi, S.; Sanguineti, M.C.; Landi, P.; Maccaferri, M.; Conti, S. Mapping QTLs Regulating Morpho-Physiological Traits and Yield: Case Studies, Shortcomings and Perspectives in Drought-Stressed Maize. Ann. Bot. 2002, 89 Spec No, 941-963. [CrossRef]

137. International Service for the Acquisition of Agri-Biotech Applications-ISAAA.Org. Available online: https://www.isaaa.org/ default.asp (accessed on 7 October 2021).

138. Unit, B. Biosafety Clearing-House. Available online: https://bch.cbd.int/ (accessed on 7 October 2021).

139. Food Safety and Quality: GM Foods Platform. Available online: http://www.fao.org/food/food-safety-quality/gm-foodsplatform/en/ (accessed on 7 October 2021). 
140. Pellegrino, E.; Bedini, S.; Nuti, M.; Ercoli, L. Impact of Genetically Engineered Maize on Agronomic, Environmental and Toxicological Traits: A Meta-Analysis of 21 Years of Field Data. Sci. Rep. 2018, 8, 3113. [CrossRef]

141. Taverniers, I.; Papazova, N.; Bertheau, Y.; De Loose, M.; Holst-Jensen, A. Gene Stacking in Transgenic Plants: Towards Compliance between Definitions, Terminology, and Detection within the EU Regulatory Framework. Environ. Biosafety Res. 2008, 7, 197-218. [CrossRef] [PubMed]

142. Ye, X.; Al-Babili, S.; Klöti, A.; Zhang, J.; Lucca, P.; Beyer, P.; Potrykus, I. Engineering the Provitamin A ( $\beta$-Carotene) Biosynthetic Pathway into (Carotenoid-Free) Rice Endosperm. Science 2000, 287, 303-305. [CrossRef]

143. Coe, E.H. A Line of Maize with High Haploid Frequency. Am. Nat. 1959, 93, 381-382. [CrossRef]

144. Liu, C.; Li, X.; Meng, D.; Zhong, Y.; Chen, C.; Dong, X.; Xu, X.; Chen, B.; Li, W.; Li, L.; et al. A 4-Bp Insertion at ZmPLA1 Encoding a Putative Phospholipase A Generates Haploid Induction in Maize. Mol. Plant 2017, 10, 520-522. [CrossRef] [PubMed]

145. Kelliher, T.; Starr, D.; Richbourg, L.; Chintamanani, S.; Delzer, B.; Nuccio, M.L.; Green, J.; Chen, Z.; McCuiston, J.; Wang, W.; et al. MATRILINEAL, a Sperm-Specific Phospholipase, Triggers Maize Haploid Induction. Nature 2017, 542, 105-109. [CrossRef]

146. Ravi, M.; Chan, S.W.L. Haploid Plants Produced by Centromere-Mediated Genome Elimination. Nature 2010, 464, 615-618. [CrossRef] [PubMed]

147. Wang, Y.; Liu, X.; Zheng, X.; Wang, W.; Yin, X.; Liu, H.; Ma, C.; Niu, X.; Zhu, J.-K.; Wang, F. Creation of Aromatic Maize by CRISPR/Cas. J. Integr. Plant Biol. 2021, 63, 1664-1670. [CrossRef] [PubMed]

148. USDA ERS—Recent Trends in GE Adoption. Available online: https://www.ers.usda.gov/data-products/adoption-ofgenetically-engineered-crops-in-the-us / recent-trends-in-ge-adoption.aspx (accessed on 8 October 2021).

149. Naegeli, H.; Bresson, J.; Dalmay, T.; Dewhurst, I.C.; Epstein, M.M.; Firbank, L.G.; Guerche, P.; Hejatko, J.; Moreno, F.J.; Mullins, E.; et al. Assessment of Genetically Modified Maize MON $87427 \times$ MON $87460 \times$ MON $89034 \times 1507 \times$ MON $87411 \times 59122$ and Subcombinations, for Food and Feed Uses, under Regulation (EC) No 1829/2003 (Application EFSA-GMO-NL-2017-139). EFSA J. 2021, 19, e06351. [CrossRef]

150. Que, Q.; Chilton, M.-D.M.; de Fontes, C.M.; He, C.; Nuccio, M.; Zhu, T.; Wu, Y.; Chen, J.S.; Shi, L. Trait Stacking in Transgenic Crops: Challenges and Opportunities. GM Crops 2010, 1, 220-229. [CrossRef] [PubMed]

151. Castañera, P.; Farinós, G.P.; Ortego, F.; Andow, D.A. Sixteen Years of Bt Maize in the EU Hotspot: Why Has Resistance Not Evolved? PLoS ONE 2016, 11, e0154200. [CrossRef]

152. Yu, Q.; Tungsuchat-Huang, T.; Verma, K.; Radler, M.R.; Maliga, P. Independent Translation of ORFs in Dicistronic Operons, Synthetic Building Blocks for Polycistronic Chloroplast Gene Expression. Plant J. 2020, 103, 2318-2329. [CrossRef] [PubMed]

153. Cody, J.P.; Graham, N.D.; Birchler, J.A. BiBAC Modification and Stable Transfer into Maize (Zea Mays) Hi-II Immature Embryos via Agrobacterium-Mediated Transformation. Curr. Protoc. Plant Biol. 2017, 2, 350-369. [CrossRef] [PubMed]

154. Birchler, J.; Han, F. Meiotic Behavior of Small Chromosomes in Maize. Front. Plant Sci. 2013, 4, 505. [CrossRef] [PubMed]

155. Su, H.; Liu, Y.; Liu, Y.; Birchler, J.A.; Han, F. The Behavior of the Maize B Chromosome and Centromere. Genes 2018, 9, 476. [CrossRef]

156. Chennakesavulu, K.; Singh, H.; Trivedi, P.K.; Jain, M.; Yadav, S.R. State-of-the-Art in CRISPR Technology and Engineering Drought, Salinity, and Thermo-Tolerant Crop Plants. Plant Cell Rep. 2021. [CrossRef]

157. Mushtaq, A.; Mir, U.S.; Hunt, C.R.; Pandita, S.; Tantray, W.W.; Bhat, A.; Pandita, R.K.; Altaf, M.; Pandita, T.K. Role of Histone Methylation in Maintenance of Genome Integrity. Genes 2021, 12, 1000. [CrossRef] [PubMed]

158. Liang, Z.; Zhang, K.; Chen, K.; Gao, C. Targeted Mutagenesis in Zea Mays Using TALENs and the CRISPR/Cas System. J. Genet. Genomics Yi Chuan Xue Bao 2014, 41, 63-68. [CrossRef] [PubMed]

159. Svitashev, S.; Young, J.K.; Schwartz, C.; Gao, H.; Falco, S.C.; Cigan, A.M. Targeted Mutagenesis, Precise Gene Editing, and Site-Specific Gene Insertion in Maize Using Cas9 and Guide RNA. Plant Physiol. 2015, 169, 931-945. [CrossRef] [PubMed]

160. Svitashev, S.; Schwartz, C.; Lenderts, B.; Young, J.K.; Mark Cigan, A. Genome Editing in Maize Directed by CRISPR-Cas9 Ribonucleoprotein Complexes. Nat. Commun. 2016, 7, 13274. [CrossRef]

161. Young, J.; Zastrow-Hayes, G.; Deschamps, S.; Svitashev, S.; Zaremba, M.; Acharya, A.; Paulraj, S.; Peterson-Burch, B.; Schwartz, C.; Djukanovic, V.; et al. CRISPR-Cas9 Editing in Maize: Systematic Evaluation of Off-Target Activity and Its Relevance in Crop Improvement. Sci. Rep. 2019, 9, 6729. [CrossRef]

162. Shi, J.; Gao, H.; Wang, H.; Lafitte, H.R.; Archibald, R.L.; Yang, M.; Hakimi, S.M.; Mo, H.; Habben, J.E. ARGOS8 Variants Generated by CRISPR-Cas9 Improve Maize Grain Yield under Field Drought Stress Conditions. Plant Biotechnol. J. 2017, 15, 207-216. [CrossRef]

163. Qi, X.; Wu, H.; Jiang, H.; Zhu, J.; Huang, C.; Zhang, X.; Liu, C.; Cheng, B. Conversion of a Normal Maize Hybrid into a Waxy Version Using in Vivo CRISPR/Cas9 Targeted Mutation Activity. Crop J. 2020, 8, 440-448. [CrossRef]

164. Schwartz, C.; Lenderts, B.; Feigenbutz, L.; Barone, P.; Llaca, V.; Fengler, K.; Svitashev, S. CRISPR-Cas9-Mediated 75.5-Mb Inversion in Maize. Nat. Plants 2020, 6, 1427-1431. [CrossRef]

165. Bharat, S.S.; Li, S.; Li, J.; Yan, L.; Xia, L. Base Editing in Plants: Current Status and Challenges. Crop J. 2020, 8, 384-395. [CrossRef]

166. Molla, K.A.; Sretenovic, S.; Bansal, K.C.; Qi, Y. Precise Plant Genome Editing Using Base Editors and Prime Editors. Nat. Plants 2021, 7, 1166-1187. [CrossRef]

167. Zong, Y.; Wang, Y.; Li, C.; Zhang, R.; Chen, K.; Ran, Y.; Qiu, J.-L.; Wang, D.; Gao, C. Precise Base Editing in Rice, Wheat and Maize with a Cas9-Cytidine Deaminase Fusion. Nat. Biotechnol. 2017, 35, 438-440. [CrossRef] 
168. Jiang, Y.-Y.; Chai, Y.-P.; Lu, M.-H.; Han, X.-L.; Lin, Q.; Zhang, Y.; Zhang, Q.; Zhou, Y.; Wang, X.-C.; Gao, C.; et al. Prime Editing Efficiently Generates W542L and S621I Double Mutations in Two ALS Genes in Maize. Genome Biol. 2020, 21, 257. [CrossRef] [PubMed]

169. Jin, S.; Lin, Q.; Luo, Y.; Zhu, Z.; Liu, G.; Li, Y.; Chen, K.; Qiu, J.-L.; Gao, C. Genome-Wide Specificity of Prime Editors in Plants. Nat. Biotechnol. 2021, 39, 1292-1299. [CrossRef]

170. Kelliher, T.; Starr, D.; Su, X.; Tang, G.; Chen, Z.; Carter, J.; Wittich, P.E.; Dong, S.; Green, J.; Burch, E.; et al. One-Step Genome Editing of Elite Crop Germplasm during Haploid Induction. Nat. Biotechnol. 2019, 37, 287-292. [CrossRef]

171. Wang, B.; Zhu, L.; Zhao, B.; Zhao, Y.; Xie, Y.; Zheng, Z.; Li, Y.; Sun, J.; Wang, H. Development of a Haploid-Inducer Mediated Genome Editing System for Accelerating Maize Breeding. Mol. Plant 2019, 12, 597-602. [CrossRef]

172. Malyska, A.; Bolla, R.; Twardowski, T. The Role of Public Opinion in Shaping Trajectories of Agricultural Biotechnology. Trends Biotechnol. 2016, 34, 530-534. [CrossRef] [PubMed]

173. Pandey, P.; Ramegowda, V.; Senthil-Kumar, M. Shared and Unique Responses of Plants to Multiple Individual Stresses and Stress Combinations: Physiological and Molecular Mechanisms. Front. Plant Sci. 2015, 6, 723. [CrossRef] [PubMed]

174. Pandey, P.; Irulappan, V.; Bagavathiannan, M.V.; Senthil-Kumar, M. Impact of Combined Abiotic and Biotic Stresses on Plant Growth and Avenues for Crop Improvement by Exploiting Physio-Morphological Traits. Front. Plant Sci. 2017, 8, 537. [CrossRef]

175. Bailey-Serres, J.; Parker, J.E.; Ainsworth, E.A.; Oldroyd, G.E.D.; Schroeder, J.I. Genetic Strategies for Improving Crop Yields. Nature 2019, 575, 109-118. [CrossRef]

176. Zandalinas, S.I.; Sengupta, S.; Fritschi, F.B.; Azad, R.K.; Nechushtai, R.; Mittler, R. The Impact of Multifactorial Stress Combination on Plant Growth and Survival. New Phytol. 2021, 230, 1034-1048. [CrossRef]

177. Zandalinas, S.I.; Fichman, Y.; Devireddy, A.R.; Sengupta, S.; Azad, R.K.; Mittler, R. Systemic Signaling during Abiotic Stress Combination in Plants. Proc. Natl. Acad. Sci. USA 2020, 117, 13810-13820. [CrossRef]

178. Mangin, B.; Casadebaig, P.; Cadic, E.; Blanchet, N.; Boniface, M.-C.; Carrère, S.; Gouzy, J.; Legrand, L.; Mayjonade, B.; Pouilly, N.; et al. Genetic Control of Plasticity of Oil Yield for Combined Abiotic Stresses Using a Joint Approach of Crop Modelling and Genome-Wide Association. Plant Cell Environ. 2017, 40, 2276-2291. [CrossRef] [PubMed]

179. Shaik, R.; Ramakrishna, W. Machine Learning Approaches Distinguish Multiple Stress Conditions Using Stress-Responsive Genes and Identify Candidate Genes for Broad Resistance in Rice. Plant Physiol. 2014, 164, 481-495. [CrossRef] [PubMed]

180. Wang, H.; Cimen, E.; Singh, N.; Buckler, E. Deep Learning for Plant Genomics and Crop Improvement. Curr. Opin. Plant Biol. 2020, 54, 34-41. [CrossRef] [PubMed]

181. Sperschneider, J. Machine Learning in Plant-Pathogen Interactions: Empowering Biological Predictions from Field Scale to Genome Scale. New Phytol. 2020, 228, 35-41. [CrossRef] [PubMed]

182. Wu, B.; Zhang, H.; Lin, L.; Wang, H.; Gao, Y.; Zhao, L.; Chen, Y.P.P.; Chen, R.; Gu, L. A Similarity Searching System for Biological Phenotype Images Using Deep Convolutional Encoder-Decoder Architecture. Curr. Bioinform. 2019, 14, 628-639. [CrossRef] 